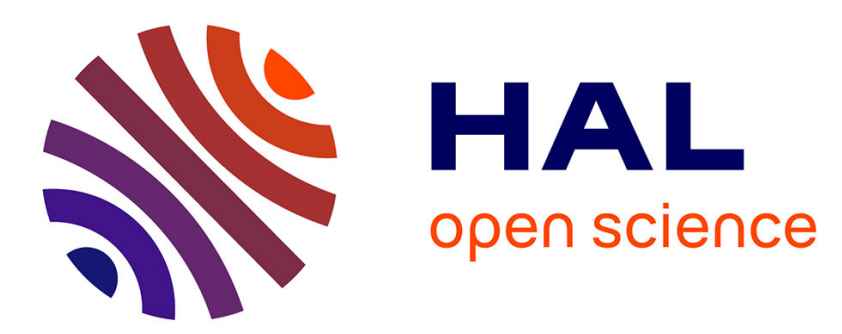

\title{
Fast-thermal coupled cores in zero power reactors: A demonstration of feasibility and pertinence for the ZEPHYR project
}

P. Ros, P. Leconte, Patrick Blaise, Hugo Doger de Spéville, Maxence Maillot

\section{- To cite this version:}

P. Ros, P. Leconte, Patrick Blaise, Hugo Doger de Spéville, Maxence Maillot. Fast-thermal coupled cores in zero power reactors: A demonstration of feasibility and pertinence for the ZEPHYR project. Annals of Nuclear Energy, 2017, 110, pp.290-305. 10.1016/j.anucene.2017.06.019 cea-02421904

HAL Id: cea-02421904 https://hal-cea.archives-ouvertes.fr/cea-02421904

Submitted on 20 Dec 2019

HAL is a multi-disciplinary open access archive for the deposit and dissemination of scientific research documents, whether they are published or not. The documents may come from teaching and research institutions in France or abroad, or from public or private research centers.
L'archive ouverte pluridisciplinaire HAL, est destinée au dépôt et à la diffusion de documents scientifiques de niveau recherche, publiés ou non, émanant des établissements d'enseignement et de recherche français ou étrangers, des laboratoires publics ou privés. 


\title{
FAST-THERMAL COUPLED CORES IN ZPRs: A DEMONSTRATION OF FEASABILITY AND PERTINENCE FOR THE ZEPHYR PROJECT
}

\author{
Paul Ros, Pierre Leconte, Patrick Blaise, Hugo Doger de Spéville, Maxence Maillot \\ CEA, DEN, DER, Cadarache \\ 13115 Saint-Paul-Lez-Durance \\ Corresponding author: paul.ros@cea.fr
}

\begin{abstract}
The development of GEN-IV fast reactor technology at an industrial scale will need significant improvement of nuclear data and related uncertainties to cope with awaited target uncertainties. Zero Power Facilities enable to answer GEN IV experiments are sparse. In France, MASURCA ZPR and the future ZEPHYR multipurpose ZPR to be built in Cadarache belong to those facilities. For this latest one, fast/thermal coupled configurations performed in MINERVE during the 1970 's have been recently revisited using modern calculation tools. The principle of a fast zone fed by a thermal booster, known from decades as the concept of coupled cores regained interest in recent years. This paper describes the concept of fast/thermal coupled core, a deeper description of the physical characteristics of the adaptation zone, and its use in the improvement of fast-spectrum nuclear data thanks to integral experiments. An optimized configuration is then presented. The preliminary design phase is performed using deterministic tools, a posteriori validated against a full Monte Carlo calculation. Particular attention is paid on the impact of the buffer zone on the spectral characteristics in the oscillation channel, as well as the sample mass characteristics required to ensure a proper signal analysis. Moreover, preliminary studies dedicated to the experimental realization of such a configuration are described, including the reactivity stability in case of an accidental flooding of the fast central zone.
\end{abstract}

Key Words: experimental mock-up, fast/thermal coupled core, spectral conversion, nuclear data.

\section{INTRODUCTION}

Today, safety requirements related to the industrial exploitation of nuclear reactors are continuously increasing. In the field of reactor physics, it concerns both existing and future concepts. The improvement of numerical calculations and a better knowledge of nuclear data represents the two main axes of $R \& D$. The experimental programs performed in Zero Power Reactors stand as a key tool in this process. They aim to qualify neutronics tools, demonstrate new concepts feasibility and improve nuclear data. As research programs dedicated to nuclear data for GEN II - III water reactors and innovative GEN IV fast spectrum reactors are successively achieved in ZPR such as MINERVE in Cadarache (Cathalau, 2014), fast- 
thermal coupled cores appear highly relevant. They consist of getting neutronics characteristics of a targeted fast-spectrum in a reduced central zone, while criticality is achieved thanks to a thermal driver zone. As this latter gathers the majority of fissions, such configurations allow an important reduction of fissile materials and a higher flexibility due to the thermal-spectrum kinetics parameters, in particular the effective neutron generation time $\Lambda_{\text {eff. }}$

Even if it was studied to use fast-thermal coupled cores at an industrial scale (Avery, 1958), those configurations have been only loaded in ZPR where many experiments were carried out. Indeed, they represent a powerful tool to measure both total (Martin-Deidier, 1979) and separated (Fahrmann, 1981 and Lehmann, 1986 and 1991) cross sections of isotopes of interest, and other important parameters such as the ratio capture over fission (Bretscher, 1970) or kinetics parameters (Milosevic, 1995).

Obviously, the design of fast-thermal coupled cores have been improved and optimized from the first experiments (ERMINE I\&II in MINERVE or CFTS-1 in RB reactor (Pesic, 1987)) to the last loaded cores (ERMINE V in MINERVE (Martin-Deidier, 1979) or HERBE in RB reactor (Pesic, 1987 and 1991)). Those improvements mainly come from the optimization of an adaptation zone. Surrounded by the thermal spectrum zone, the adaptation zone is designed in order to achieve the targeted fast spectrum in the center of the measurement zone. While literature is quite fruitful about examples through descriptions of loaded cores, it appears quite poor about the design of this intermediate adaptation zone and its associated physics. However, coupled cores regained interest in recent years, through the development of new innovative designs (Youinou, 2016) and associated calculation methodologies (Aufiero ,2016). The proposed study could address a complementary design.

This paper presents the neutronics specificities of the fast-thermal coupled cores for future experimental programs dedicated to nuclear data for sodium fast GEN IV reactors. It is incorporated within the framework of R\&D studies for ZEPHYR (Zero power Experimental PHYsics Reactor), a future facility to be built in Cadarache around 2026 (Blaise, 2016). Through a progressive optimization taking benefit from the MASURCA fast ZPR and its available fuel stockpile, this study aim to answer recurrent questions about such configurations. Do the neutronics conditions - forward and adjoint flux - of a fast core can be reproduced at the center of a fast-thermal coupled core? Do the surrounded zones - thermal and adaptation - keep a spectral influence in the center of the fast zone? All the previous fastthermal coupled configurations are based on a very high enriched thermal zone (enrichment higher than 80\%); is a low enriched thermal zone possible? Finally, how does a fast-thermal coupled core respond to an accidental flooding? All those questions are answered in the following paragraphs. In the first one, we will detail the methodology and the used numerical tools for the proper design of the fast/thermal configurations. In the two next chapters, we will present the design of a new fast/thermal coupled core. Then, we will characterize the sensitivity of the reaction rates and oscillation measurements to surrounding Nuclear Data in order to characterize the contribution of the converter and driver zones uncertainties to the central flux. Finally, flooding studies will be detailed to assure a criticality control in case of an accidental water insertion in the fast zone. 


\section{METHODOLOGY AND TOOLS}

The main goal of fast-thermal experimental programs is to measure integral total crosssections of several isotopes of interest in a targeted fast spectrum through accurate reactivity effects measurements. That is why the central zone is also called the "measurement zone" or "experimental zone". Therefore, the neutronics characteristics of this spectrum have to be reproduced in the center of the fast-thermal coupled configuration. The work presented here is based on a PHENIX-like fast unit cell, called ZONA1, from ZONA1 core of the ERMINE V program (Martin-Deidier, 1979) and whose materials are coming from the MASURCA stockpile. ZONA1 cell is made of 6 enriched MOx rodlets, 2 natural UOx rodlets and 8 sodium pellets. It is 12 inches high and about 2 inches large. It represents an intermediate spectrum, between the two cores of PHENIX, and is represented below on Figure 1:

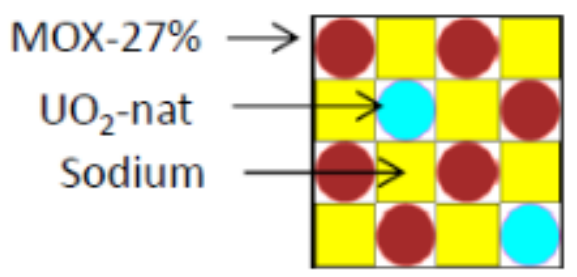

Figure 1 : ZONA1 cell

A first configuration is made of those ZONA1 cells, 36 inches high, that corresponds to the fissile height of the core. The radius is adapted in order to be critical. This entire fast configuration stands for the reference case and will stand as a target for both spectrum and reactivity effects to be reproduced in the mock-up. By coupling a center part of this reference configuration to a peripheral thermal zone, a basic coupled configuration is obtained. As it will be explained in section 2, this configuration exhibits the strengths and weaknesses of a trivial coupling. Thanks to those elements, an adaptation zone is designed step by step in order to get a deeper understanding of the physical specificities and obtain quantitative results for its optimization.

Although the study is built on a precise fast cell, ZONA1, and is intended to reproduce its characteristics, the methodology and the conclusions about the adaptation zone are more general.

Simplified calculations are performed using the fast-lattice deterministic ECCO/ERANOS system of codes (Rimpault, 2002). It enables an accurate calculation of the fast zone - the one of interest - whereas the thermal zone is also well computed thanks to a 1968-energy-group cell calculation based on subgroups and probability table methods for self-shielding. Core calculations are performed in (R-Z) geometry using the BISTRO transport code in $\mathrm{S}_{4}-\mathrm{P}_{1}$ and 33 energy-groups derived from the 172 groups X-MAS energy mesh. This calculation scheme results from a compromise between accuracy in both fast and thermal zones and CPU time for each calculation. 
As it has been already mentioned, one of the first main questions about fast-thermal coupled cores is: "Is the targeted fast spectrum well reproduced in the center of the coupled configuration?". Several indicators can be used to evaluate the representativeness. The 33groups energy profile of the forward flux gives a first overview of the whole energy domain. Classical spectral indices covering the fast, epithermal and thermal energy ranges, are also used in order to get a quantitative modification of spectra. Considering that $\tau_{R}(X)$ is the reaction rate for a reaction $R$ of an isotope $X$, we have studied $\tau_{f}\left({ }^{238} U\right) / \tau_{f}\left({ }^{235} U\right)$ and $\tau_{f}\left({ }^{237} N p\right) / \tau_{f}\left({ }^{235} U\right)$ for the fast range because of the threshold fission cross-sections of ${ }^{238} \mathrm{U}$ (above $1 \mathrm{MeV}$ ) and ${ }^{237} \mathrm{~Np}$ (above $500 \mathrm{keV}$ ). In the intermediate energy range, the ratio $\tau_{C}\left({ }^{238} U\right) / \tau_{f}\left({ }^{235} U\right)$ is used because of the multiple large resonances in the ${ }^{238} \mathrm{U}$ capture crosssection. And in the thermal energy range, the $1 / v$ profile of the $(n, \alpha)$ cross section of ${ }^{10} \mathrm{~B}$ gives a powerful evaluation of the proportion of neutrons below $10 \mathrm{eV}$ thanks to the $\tau_{A}\left({ }^{10} B\right) / \tau_{f}\left({ }^{235} U\right)$ ratio. However those tools are not sufficient as it will be demonstrated. Then, a 7-energy-group division - recommended in (Palmiotti and Salvatores, 2011) - of the forward flux is also used in order to easily see large energy group repartition. Table 1 reproduces the energy boundaries:

\begin{tabular}{|c|c|}
\hline Group & $\begin{array}{c}\text { Upper Energy in } \\
\text { group (in eV) }\end{array}$ \\
\hline 1 & $1,96403 \mathrm{E}+07$ \\
\hline 2 & $2,23130 \mathrm{E}+06$ \\
\hline 3 & $4,97871 \mathrm{E}+05$ \\
\hline 4 & $6,73795 \mathrm{E}+04$ \\
\hline 5 & $2,03468 \mathrm{E}+03$ \\
\hline 6 & $2,26033 \mathrm{E}+01$ \\
\hline 7 & $5,40000 \mathrm{E}-01$ \\
\hline
\end{tabular}

Table 1: 7 groups energy division

Finally, the energy profile of the adjoint flux is analyzed for the optimized configurations. All these indicators are evaluated in the centers of the coupled and the fast configurations, that correspond to the oscillation channels.

The next parts (2, 3 and 4) contain a deeper understanding of the spectral adaptation than in previous work (Ros, 2016). Besides, a complete demonstration of the pertinence and reliability of fast-thermal coupled cores is presented. 


\section{SPECTRAL ADAPTATION ZONE: NEEDS, DEFINITION AND OPTIMIZATION}

\subsection{Simple coupled configurations}

As mentioned before, simple calculations were performed on very simple coupled configurations to clearly identify the needs and main characteristics of spectral adaptation. A set of two configurations in R-Z geometry is used. It consists of a juxtaposition of two zones, a ZONA1 like in the center surrounded by a LWR-type one composed of $\mathrm{UO}_{2} \mathrm{PWR}$ fuel pins available in the EOLE ZPR. The fast center zone is either a $25-\mathrm{cm}$ radius one (referred after as 1) or a $45-\mathrm{cm}$ one (referred after as 2). The size of the LWR-zone is fixed in order to get a critical core.

Below (Figure 2), are presented radial profiles of the spectral index $\tau_{f}\left({ }^{238} U\right) / \tau_{f}\left({ }^{235} U\right)$ in both configurations to compare the proportion of fast neutrons above $1 \mathrm{MeV}$ :

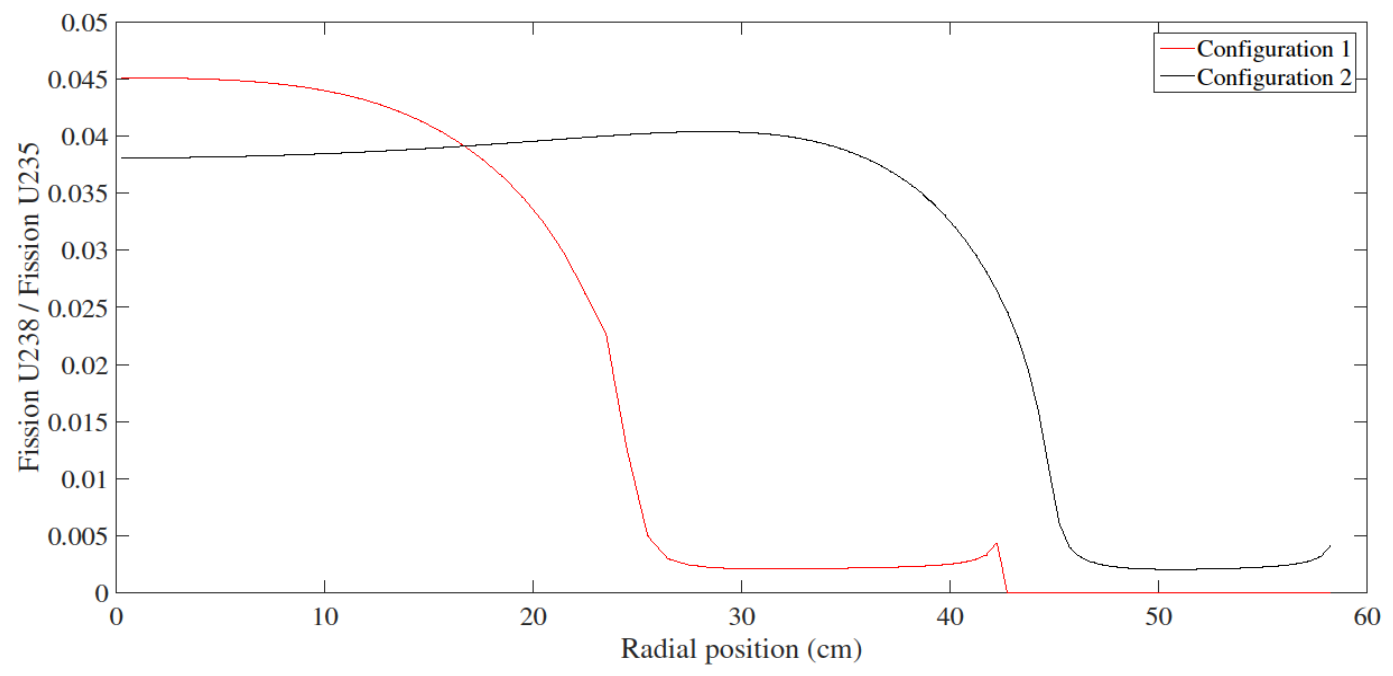

Figure 2: Radial spectral index FU8/FU5 in simple coupled cores

It has to be noted that the max values of radial spectral index differ between the two configurations. Besides, in configuration 2 , the maximum is around $\mathrm{R}=30 \mathrm{~cm}$, and the spectral index is decreasing in the vicinity of the center. This is confirmed by the other spectral indices (Table 2):

\begin{tabular}{|c|c|c|c|}
\hline Spectral indices & Reference & Configuration 1 & Configuration 2 \\
\hline$\tau_{f}\left({ }^{238} U\right) / \tau_{f}\left({ }^{235} U\right)$ & $3.60 \mathrm{E}-02$ & $4.51 \mathrm{E}-02$ & $3.81 \mathrm{E}-02$ \\
\hline$\tau_{f}\left({ }^{237} N p\right) / \tau_{f}\left({ }^{235} U\right)$ & $2.37 \mathrm{E}-01$ & $2.89 \mathrm{E}-01$ & $2.51 \mathrm{E}-01$ \\
\hline$\left.\tau_{C}\left({ }^{238} U\right) / \tau_{f}{ }^{235} U\right)$ & $1.28 \mathrm{E}-01$ & $1.15 \mathrm{E}-01$ & $1.26 \mathrm{E}-01$ \\
\hline$\tau_{A}\left({ }^{10} B\right) / \tau_{f}\left({ }^{235} U\right)$ & 1.29 & 1.41 & 1.26 \\
\hline
\end{tabular}

Table 2: Spectral indices in simple coupled cores 
Surprisingly, 1 has a higher fast spectral index: fluxes above $1 \mathrm{MeV}$ are higher in both coupled configurations than in the reference configuration whereas a quite consequent thermal spectrum remains. Then, 33-energy-group fluxes are evaluated for both configurations in the core centers to get a deeper understanding of such values:

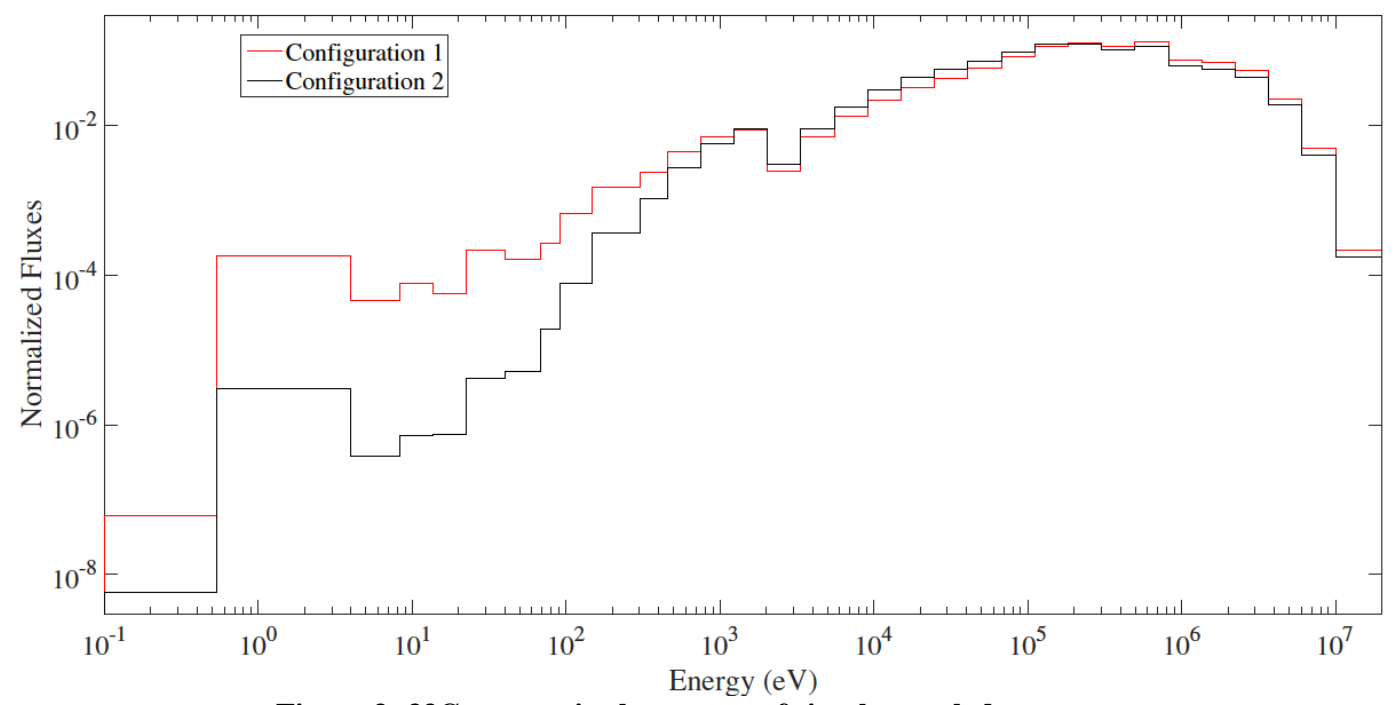

Figure 3: 33G spectra in the centers of simple coupled cores

By comparison of these two profiles, it appears that the influence of the residual thermal neutrons from the driver zone can be hidden by highly energetic fission neutrons, coming from the interface between the two zones. They increase fast spectral indices such as $\tau_{f}\left({ }^{238} U\right) / \tau_{f}\left({ }^{235} U\right)$ due to the threshold fission cross section of ${ }^{238} U$. That is why the 7 energy-group division of the forward flux is also used, in addition of spectral indices to get better comparisons. Table 3 reproduces the energy decomposition of the direct fluxes:

\begin{tabular}{|c|c|c|c|c|c|c|c|}
\hline Group & $\mathbf{1}$ & $\mathbf{2}$ & $\mathbf{3}$ & $\mathbf{4}$ & $\mathbf{5}$ & $\mathbf{6}$ & $\mathbf{7}$ \\
\hline $\begin{array}{c}\text { Proportion of neutrons } \\
\text { Configuration 1 (in \%) }\end{array}$ & 8.2 & 27.7 & 43.6 & 17.9 & 2.6 & $9.2 \mathrm{E}-02$ & $2.3 \mathrm{E}-05$ \\
\hline $\begin{array}{c}\text { Proportion of neutrons } \\
\text { Configuration 2 (in \%) }\end{array}$ & 6.7 & 23.5 & 44.5 & 23.4 & 1.9 & $1.4 \mathrm{E}-03$ & $3.6 \mathrm{E}-06$ \\
\hline $\begin{array}{c}\text { Proportion of neutrons } \\
\text { Reference (in \%) }\end{array}$ & 6.5 & 22.7 & 43.6 & 25.0 & 2.1 & $1.2 \mathrm{E}-05$ & $2.6 \mathrm{E}-06$ \\
\hline
\end{tabular}

Table 3: 7G spectra of simple coupled cores

These configurations, and especially the configuration 2, also clarify the structure of the spectral adaptation, which is a two steps phenomenon. First, thermal neutrons from the driver zone are converted into fast neutrons and then adapted to the targeted spectrum by subsequent slowing-down.

\subsection{The conversion zone}

A first boundary between the thermal driver zone and the fast zone is called the conversion zone. Its role is to suppress the main part of thermal and epi-thermal neutron flux coming 
from the thermal zone so as to get fast neutrons. At this step, the fast spectrum is not the targeted one from the reference. Two techniques could be used: on the one hand thermal and epi-thermal absorbent isotopes $\left({ }^{10} \mathrm{~B}\right.$ for instance) can be used to cut the low-energy part of the spectrum, or, on the other hand, fissile isotopes in order to convert slowed-down neutrons into fission neutrons. In ZPR, as the fast flux intensity is relatively small (around $10^{9}$ neutrons. $\mathrm{cm}^{-2} \cdot \mathrm{s}^{-1}$ compared to $10^{14}$ neutrons. $\mathrm{cm}^{-2} \cdot \mathrm{s}^{-1}$ in Material Testing Reactors), the second technique appears to be more efficient. Indeed, neutrons from the thermal zone strongly contribute to the criticality and are highly efficient for fission. Then, capturing them would highly reduce the coupling benefit and then increase the size and need of fissile fuel of the thermal driver zone. Moreover, it should be more relevant to produce fast neutrons the furthest from the central position of the core to maximize the fast neutron flux.

\subsection{The transition zone}

After the conversion zone, the thermal neutrons transformed into fast ones are too energetic. Consequently, a transition zone stands as a first step to the targeted fast spectrum. The conversion zone produces fission neutrons and still presents residual thermal and epi-thermal neutrons. The role of the transition zone is to soften fission neutrons and to cut off the residual thermalized neutrons. Several sizes of materials with scattering properties (stainless steel, graphite, natural $\mathrm{UO}_{2}$ ) were tested. As graphite is a better scatterer than natural $\mathrm{UO}_{2}$ with a very low absorption cross section, it increases the thermal and epithermal flux whereas uranium resonances capture such neutrons. That is why graphite is not suitable for our purpose and therefore natural $\mathrm{UO}_{2}$ appeared to be the best candidate due to an adapted specific slowing-down power $\xi \Sigma_{S} / \Sigma_{a}$.

\section{PRESENTATION OF TWO OPTIMIZED CONFIGURATIONS}

\subsection{An optimized configuration from the step by step methodology}

In the first steps of the ZEPHYR project, fast-thermal coupled cores have been identified as strategic configurations as far as dimensions are concerned. Then, the optimization studies presented here tried to use an entire fast zone similar to the one in MINERVE (Cathalau, 2014 and Martin-Deidier, 1979), which is $35-\mathrm{cm}$ radius. Here, the ZONA1 zone has a radius of $24 \mathrm{~cm}$ which allows 9 ZONA1 cells. Then, from the optimization calculations, a conversion zone in enriched fissile materials $\left(30 \%\right.$ of ${ }^{235} \mathrm{U}$ ) and a transition zone in natural $\mathrm{UO}_{2}$ are designed. The use of uranium isotopes in the adaptation zone also implies a greater fraction of delayed neutrons $\beta_{\text {eff }}$ than in a plutonium-based configuration. $\beta_{\text {eff }}$ and $\Lambda_{\text {eff }}$ calculations are detailed in section 3.2 . 
The optimal configuration is presented below. The spectral indices are calculated in the center of the configuration and compared to the fast ones in order to point out the very good similarity obtained.
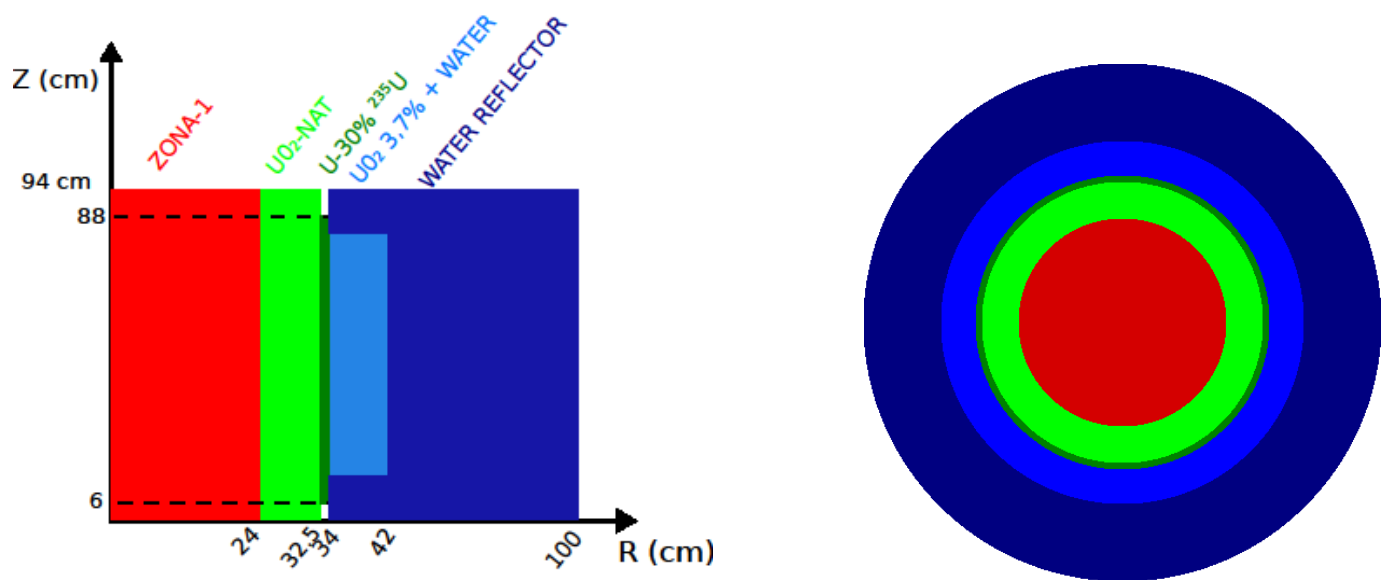

Figure 4: Optimized configuration in (R-Z) geometry (left) and radial cutting at mid core (right)

\begin{tabular}{|c|c|c|}
\hline Spectral indices & Reference & $\begin{array}{c}\text { Optimized } \\
\text { Configuration }\end{array}$ \\
\hline$\tau_{f}\left({ }^{238} U\right) / \tau_{f}\left({ }^{235} U\right)$ & $3.604 \mathrm{E}-02$ & $3.601 \mathrm{E}-02$ \\
\hline$\tau_{f}\left({ }^{237} N p\right) / \tau_{f}\left({ }^{235} U\right)$ & $2.375 \mathrm{E}-01$ & $2.379 \mathrm{E}-01$ \\
\hline$\tau_{C}\left({ }^{238} U\right) / \tau_{f}\left({ }^{235} U\right)$ & $1.282 \mathrm{E}-01$ & $1.269 \mathrm{E}-01$ \\
\hline$\tau_{A}\left({ }^{10} B\right) / \tau_{f}\left({ }^{235} U\right)$ & 1.292 & 1.313 \\
\hline
\end{tabular}

Table 4: 7G spectrum of Optimized configuration

The 7 energy-group division of the forward flux is also calculated and compared to the reference in Table 5:

\begin{tabular}{|c|c|c|c|c|c|c|c|}
\hline Group & $\mathbf{1}$ & $\mathbf{2}$ & $\mathbf{3}$ & $\mathbf{4}$ & $\mathbf{5}$ & $\mathbf{6}$ & $\mathbf{7}$ \\
\hline $\begin{array}{c}\text { Optimized configuration } \\
\text { (in \%) }\end{array}$ & 6.5 & 22.9 & 44.0 & 24.4 & 2.2 & $1.3 \mathrm{E}-02$ & $5.6 \mathrm{E}-06$ \\
\hline $\begin{array}{c}\text { Reference configuration } \\
\text { (in \%) }\end{array}$ & 6.5 & 22.7 & 43.6 & 25.0 & 2.1 & $1.2 \mathrm{E}-05$ & $2.6 \mathrm{E}-06$ \\
\hline
\end{tabular}

Table 4: 7G spectrum of Optimized configuration

In this configuration, the thermal driver zone provides $57 \%$ of fissions whereas the ZONA1 central zone stands for $12 \%$ and the remaining fissions are located in the conversion zone. The remaining thermal and epithermal components seen in the 7 energy-group division of the forward flux is tackled thanks to a $\mathrm{B}_{4} \mathrm{C}$ ring, mainly in group 6 .

\subsection{Effect of a $\mathrm{B}_{4} \mathrm{C}$ ring}

$\mathrm{A} \mathrm{B}_{4} \mathrm{C}$ ring is introduced in the adaptation zone. Its position results from a compromise. Indeed, to get a full benefice of the thermal driver zone, the $\mathrm{B}_{4} \mathrm{C}$ ring has to be far from the 
interface between the conversion and the thermal zones, but it should not disturb the neutronics conditions in the center. That is why the ring is placed between the ZONA1 and the transition zones. This configuration is also better designed to tackle reactivity insertion in case of an accidental flooding of the fast central zone (developed in section 5).

Then, a better adaptation is obtained:
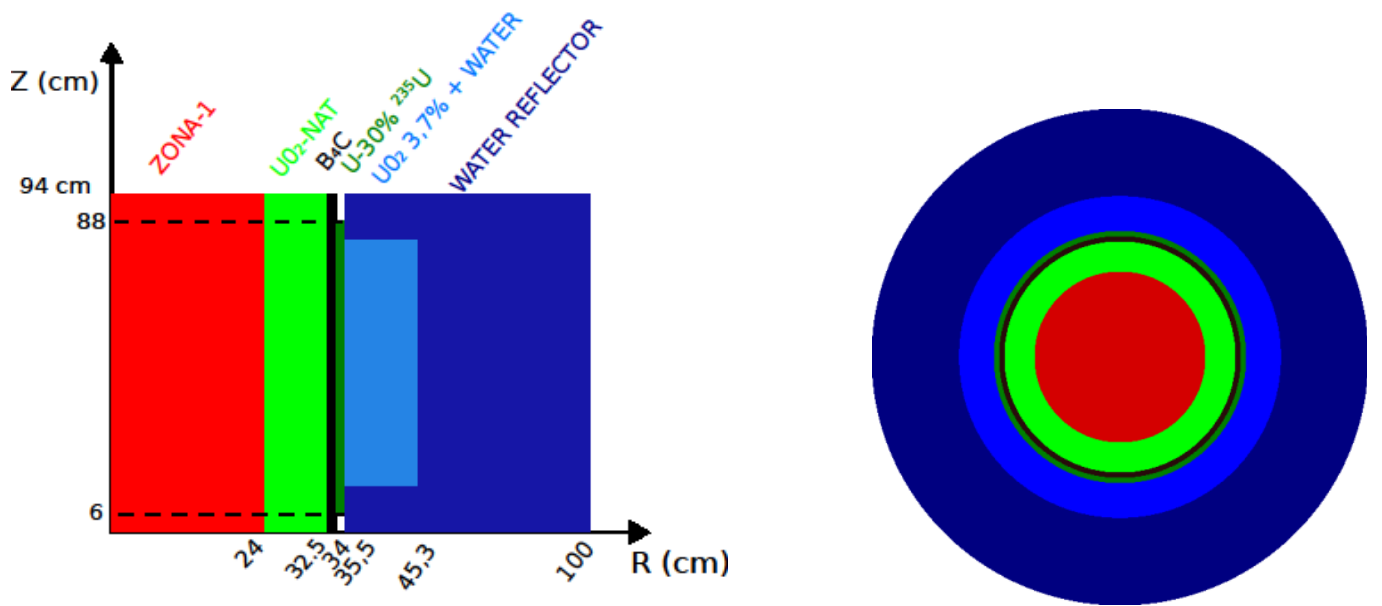

Figure 5: Optimized configuration with $B_{4} C$ in (R-Z) geometry (right) and radial cutting at mid core (right)

\begin{tabular}{|c|c|c|}
\hline Spectral indices & Reference & $\begin{array}{c}\text { Optimized } \\
\text { Configuration } \\
\text { with } \mathrm{B}_{4} \mathrm{C}\end{array}$ \\
\hline$\tau_{f}\left({ }^{238} U\right) / \tau_{f}\left({ }^{235} U\right)$ & $3.604 \mathrm{E}-02$ & $3.594 \mathrm{E}-02$ \\
\hline$\tau_{f}\left({ }^{237} N p\right) / \tau_{f}\left({ }^{235} U\right)$ & $2.375 \mathrm{E}-01$ & $2.372 \mathrm{E}-01$ \\
\hline$\tau_{C}\left({ }^{238} U\right) / \tau_{f}\left({ }^{235} U\right)$ & $1.282 \mathrm{E}-01$ & $1.275 \mathrm{E}-01$ \\
\hline$\tau_{A}\left({ }^{10} B\right) / \tau_{f}\left({ }^{235} U\right)$ & 1.292 & 1.300 \\
\hline
\end{tabular}

Table 5: Spectral indices - Optimized configuration with $\mathrm{B}_{4} \mathrm{C}$

\begin{tabular}{|c|c|c|c|c|c|c|c|}
\hline Group & $\mathbf{1}$ & $\mathbf{2}$ & $\mathbf{3}$ & $\mathbf{4}$ & $\mathbf{5}$ & $\mathbf{6}$ & $\mathbf{7}$ \\
\hline $\begin{array}{c}\text { Optimized configuration } \\
\text { with B } \mathrm{C} \text { (in \%) }\end{array}$ & 6.6 & 22.9 & 43.5 & 24.7 & 2.3 & $9.1 \mathrm{E}-04$ & $2.6 \mathrm{E}-06$ \\
\hline $\begin{array}{c}\text { Reference configuration } \\
\text { (in \%) }\end{array}$ & 6.5 & 22.7 & 43.6 & 25.0 & 2.1 & $1.2 \mathrm{E}-05$ & $2.6 \mathrm{E}-06$ \\
\hline
\end{tabular}

Table 6: 7G spectrum of Optimized configuration

In this optimized configuration with $\mathrm{B}_{4} \mathrm{C}, 61 \%$ of fissions are provided by the thermal zone and $10 \%$ come from the ZONA1 zone.

\subsection{Adjoint flux characteristics}

Besides the characterization of the forward flux, the energy profile of the adjoint flux is an important element. Indeed, the goal is to perform reactivity effect measurement through the oscillation technique (Foell, 1972). The variation of reactivity in a given configuration 
between a case where the sample is out of the core (called REF) and a case where the sample is put in the core center (called PERT) is given by $\Delta \rho=\frac{\left\langle\Phi_{\mathrm{REF}}^{+} ;\left(-\Delta \mathrm{L}+\Delta \mathrm{T}+\frac{\Delta \mathrm{F}}{\mathrm{k}_{\mathrm{REF}}}\right) \Phi_{\mathrm{PERT}}\right\rangle}{\left\langle\Phi_{\mathrm{REF}}^{+} ; \mathrm{F}_{\mathrm{PERT}} \Phi_{\mathrm{PERT}}\right\rangle}$. In this expression, the three operators $\mathrm{F}, \mathrm{T}$ and $\mathrm{L}$ are linked by the equation $\mathrm{L} \Phi=\left(\mathrm{T}+\frac{1}{\mathrm{k}} \mathrm{F}\right) \Phi$ and stand for:

- $\quad(\mathrm{L} \Phi)(\overrightarrow{\mathrm{r}}, \mathrm{E}, \vec{\Omega})=\left(\vec{\Omega} \cdot \vec{\nabla}+\sum(\overrightarrow{\mathrm{r}}, \mathrm{E})\right) \Phi(\overrightarrow{\mathrm{r}}, \mathrm{E})$

- $\quad(\mathrm{T} \Phi)(\overrightarrow{\mathrm{r}}, \mathrm{E}, \vec{\Omega})=\int_{\mathrm{E}=0}^{+\infty} \int_{4 \pi} \sum_{\mathrm{S}}\left(\overrightarrow{\mathrm{r}}, \mathrm{E}^{\prime}, \vec{\Omega}^{\prime} \rightarrow \mathrm{E}, \vec{\Omega}\right) \Phi\left(\overrightarrow{\mathrm{r}}, \mathrm{E}^{\prime}, \overrightarrow{\Omega^{\prime}}\right) \mathrm{dE} \mathrm{E}^{\prime} \mathrm{d} \vec{\Omega}^{\prime}$

- $\quad(\mathrm{F} \Phi)(\overrightarrow{\mathrm{r}}, \mathrm{E}, \vec{\Omega})=\sum_{\mathrm{i}} \frac{\chi_{\mathrm{i}}(\mathrm{E})}{4 \pi} \int_{\mathrm{E}^{\prime}=0}^{+\infty} v_{\mathrm{i}} \sum_{\mathrm{f}, \mathrm{i}}\left(\overrightarrow{\mathrm{r}}, \mathrm{E}^{\prime}\right) \Phi\left(\overrightarrow{\mathrm{r}}, \mathrm{E}^{\prime}, \vec{\Omega}\right) \mathrm{dE} \mathrm{E}^{\prime}$ where $i$ refers to fissile isotopes

Then, it appears that the adjoint flux of the reference configuration has to be well reproduced in the center of the coupled core. The adjoint fluxes of the two optimized configurations are compared to the adjoint flux in the center of the reference configuration through a 33 energygroups division in Figure 6. The upper part reproduces the energy distribution of the adjoint flux, whereas the lower part reproduces the discrepancies between the coupled configurations (with or without $\mathrm{B}_{4} \mathrm{C}$ ) and the reference adjoint fluxes.
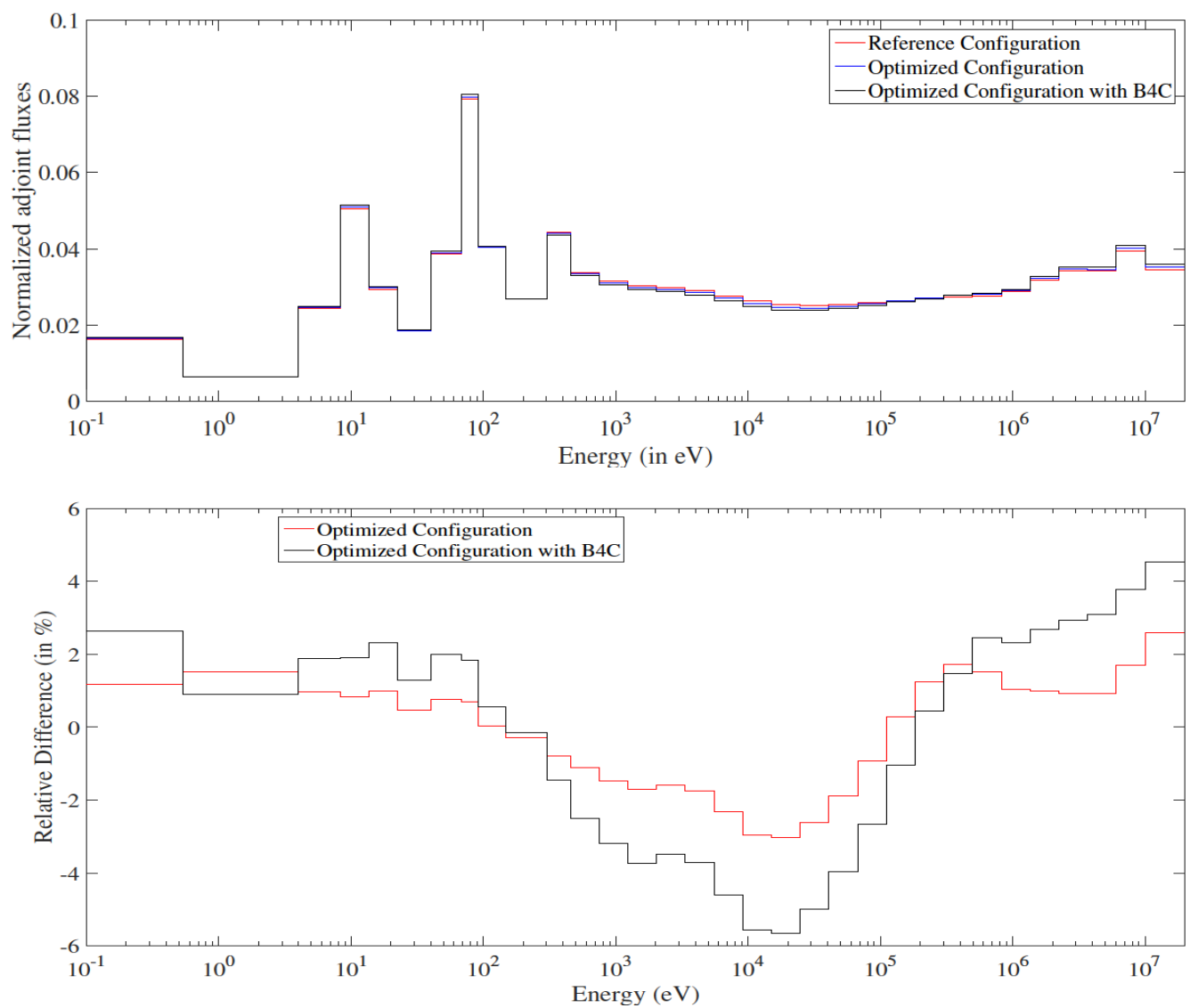

Figure 6: Comparison of adjoint fluxes for both optimized configurations to the reference 
The presence of the $\mathrm{B}_{4} \mathrm{C}$ ring slightly debases the energy profile of the adjoint flux. Nevertheless, in the most important groups $(2,3,6,7)$ the difference with the reference case is between -2 and $+2 \%$.

As several different zones are coupled, the radial profile of the adjoint flux along the core mid plane is original and brings the information of two separate fissile zones:

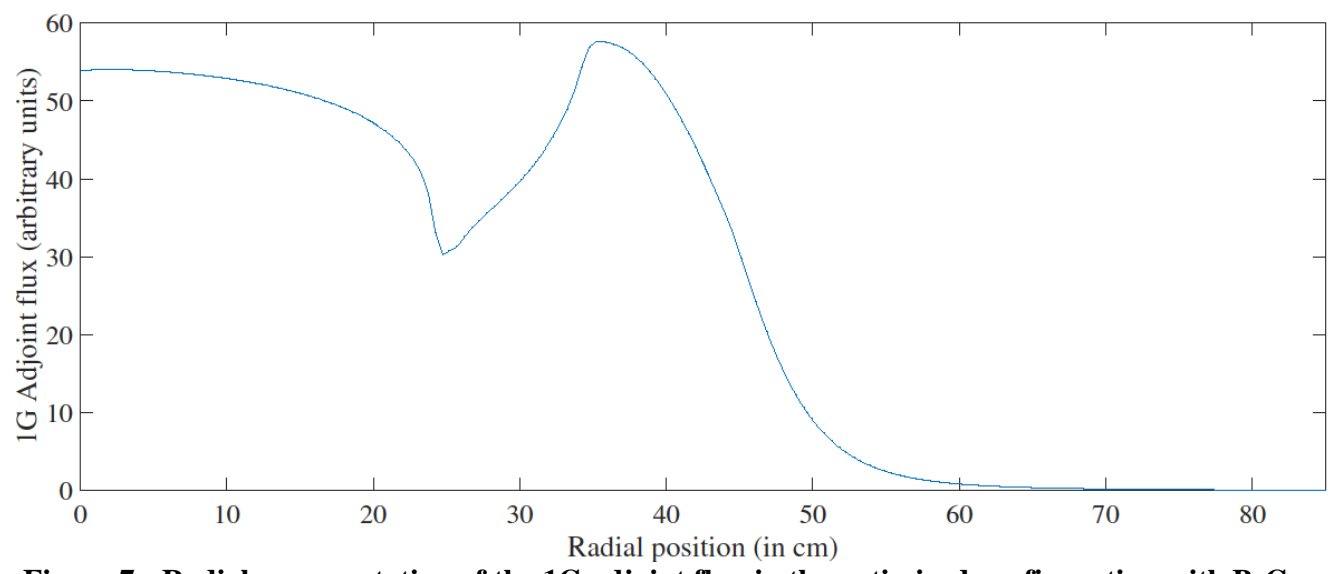

Figure 7 : Radial representation of the $1 \mathrm{G}$ adjoint flux in the optimized configuration with $\mathrm{B}_{4} \mathrm{C}$

This figure illustrates the importance of the high enriched Uranium ring and the decoupling effect of the transition zone around $\mathrm{R}=25 \mathrm{~cm}$.

The fraction of delayed neutrons $\beta_{\text {eff }}$ and the effective neutron lifetime $\Lambda_{\text {eff }}$ have been calculated thanks to a dedicated module in the BISTRO code (Rimpault, 2002). In the optimized configuration with a $\mathrm{B}_{4} \mathrm{C}$ ring, $\beta_{\mathrm{eff}}$ is $742 \mathrm{pcm}$ whereas in the reference configuration $\beta_{\text {eff }}$ is $403 \mathrm{pcm}$. This difference comes from the large proportion of Uranium isotopes. The effective neutron lifetime is $17 \mu \mathrm{s}$ in the optimized configuration with a $\mathrm{B}_{4} \mathrm{C}$ ring whereas its value in the fast reference configuration equals $0.3 \mu \mathrm{s}$.

This value of $742 \mathrm{pcm}$ brings additional safety margins during the experimental programs.

Finally, the configuration with $a \mathrm{~B}_{4} \mathrm{C}$ ring is taken as the most optimized one after our calculations.

\subsection{Validation through Monte-Carlo calculations}

Previous results have been obtained thanks to approximate calculations. An exact calculation is however necessary to get a full demonstration of the performance of the last optimized configuration. This is obtained with a Monte-Carlo calculation by TRIPOLI-4® (Brun, 2015). It relies on an exact 3D geometry description and continuous cross-sections and fluxes in both energy and angle. A representation of the geometry in plane (X-Y) is presented in figure 8 below: 


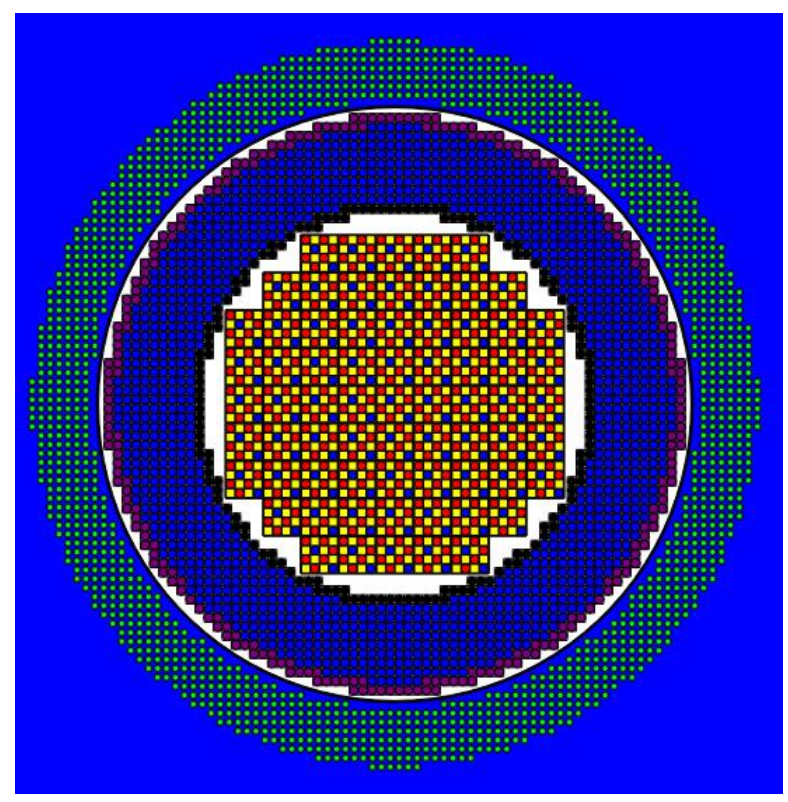

Figure 8: $\mathrm{X}$-Y representation of the TRIPOLI4® modelling for the optimized configuration with $\mathrm{B}_{4} \mathrm{C}$ Blue : light water - Green : $\mathrm{UO}_{2} 3.7 \%$ enrichment - Purple : Metallic U 30\% enrichment Navy : natural $\mathrm{UO}_{2}-$ Black : $\mathrm{B}_{4} \mathrm{C}$ absorbent - White : Air The central cells are the one presented in Fig.1

Results are presented here, proving that the awaited spectral adaptation is well performed:

\begin{tabular}{|c|c|c|c|c|}
\hline Spectral indices & Reference & Uncertainty (in \%) & Optimized Configuration $\mathrm{B}_{4} \mathrm{C}$ & Uncertainty (in \%) \\
\hline$\tau_{f}\left({ }^{238} U\right) / \tau_{f}\left({ }^{235} U\right)$ & $3,396 \mathrm{E}-02$ & 0,04 & $3,410 \mathrm{E}-02$ & 0,05 \\
\hline$\tau_{f}\left({ }^{237} N p\right) / \tau_{f}\left({ }^{235} U\right)$ & $2,271 \mathrm{E}-01$ & 0,03 & $2,277 \mathrm{E}-01$ & 0,03 \\
\hline$\tau_{C}\left({ }^{238} U\right) / \tau_{f}\left({ }^{235} U\right)$ & $1,308 \mathrm{E}-01$ & 0,03 & $1,302 \mathrm{E}-01$ & 0,04 \\
\hline$\tau_{A}\left({ }^{10} B\right) / \tau_{f}\left({ }^{235} U\right)$ & 1,306 & 0,03 & 1,307 & 0,04 \\
\hline
\end{tabular}

Table 7: TRIPOLI4® spectral indices in both Reference and Optimized configuration with B4C

\begin{tabular}{|c|c|c|}
\hline Spectral indices & Difference (in \%) & $\begin{array}{c}\text { Uncertainty on the } \\
\text { difference (in \%) }\end{array}$ \\
\hline$\tau_{f}\left({ }^{238} U\right) / \tau_{f}\left({ }^{235} U\right)$ & 0,393 & 0,06 \\
\hline$\tau_{f}\left({ }^{237} N p\right) / \tau_{f}\left({ }^{235} U\right)$ & 0,248 & 0,04 \\
\hline$\tau_{C}\left({ }^{238} U\right) / \tau_{f}\left({ }^{235} U\right)$ & $-0,444$ & 0,05 \\
\hline$\tau_{A}\left({ }^{10} B\right) / \tau_{f}\left({ }^{235} U\right)$ & 0,042 & 0,05 \\
\hline
\end{tabular}

Table 8: TRIPOLI4® differences on spectral indices

\begin{tabular}{|c|c|c|c|c|c|c|c|}
\hline Group & 1 & 2 & 3 & 4 & 5 & 6 & 7 \\
\hline Optimized configuration $\mathrm{B}_{4} \mathrm{C}$ (in \%) & 6.26 & 22.6 & 43.8 & 25.0 & 2.31 & $2.63 \mathrm{E}-03$ & $5.31 \mathrm{E}-06$ \\
\hline Uncertainty (in \%) & 0.11 & 0.06 & 0.05 & 0.07 & 0.22 & 5.5 & 41 \\
\hline Reference configuration (in \%) & 6.21 & 22.6 & 43.6 & 25.2 & 2.34 & $1.83 \mathrm{E}-05$ & $4.23 \mathrm{E}-06$ \\
\hline Uncertainty (in \%) & 0.05 & 0.03 & 0.02 & 0.03 & 0.09 & 23 & 28 \\
\hline
\end{tabular}

Table 9: TRIPOLI4® 7G spectra of both Reference and Optimized configuration with B4C 
This set of Monte-Carlo calculations confirms that the optimized configuration with a $\mathrm{B}_{4} \mathrm{C}$ ring satisfies the spectral adaptation goal. It also demonstrates that fast-thermal coupled configurations are possible in a reduced volume. This key point increases the feasibility of such experiments in the future ZEPHYR facility.

\section{ARE THE CHARACTERISTICS IN THE CORE CENTER INDEPENDENT FROM THE OUTLYING ZONES?}

\subsection{Beyond the direct terms}

Neutronics characteristics obtained in the center of the optimized configuration come successively from the thermal driver zone, the conversion zone, the transition zone, and then the fast ZONA 1 zone. Each one of them has strongly different characteristics, whose combination allows to get the targeted fast spectrum in the center. For instance, for a reaction rate ratio $R=\frac{\left\langle\sigma_{n} ; \Phi\right\rangle}{\left\langle\sigma_{d} ; \Phi\right\rangle}$. At first order, the relative variation of $\mathrm{R}$ is given by given by the following formula: $\frac{\delta R}{R} \approx \underbrace{\frac{\left\langle\delta \sigma_{n} ; \Phi\right\rangle}{\left\langle\sigma_{n} ; \Phi\right\rangle}-\frac{\left\langle\delta \sigma_{d} ; \Phi\right\rangle}{\left\langle\sigma_{d} ; \Phi\right\rangle}}_{\text {Direct }}+\underbrace{\left\langle\frac{\sigma_{n}}{\left\langle\sigma_{n} ; \Phi\right\rangle}-\frac{\sigma_{d}}{\left\langle\sigma_{d} ; \Phi\right\rangle} ; \delta \Phi\right\rangle}_{\text {Indirect }}$ [18]. The two first terms are called "direct" contributions: when a local perturbation is introduced, the local cross sections are modified. The last term is the "indirect" contribution: the flux in the center comes from the whole reactor and a perturbation in a peripheral point could modify the flux in the core center. Then, even peripheral elements can have a strong contribution on a locally centered measurement.

As far as the optimized coupled core configuration is concerned, the peripheral uranium zones (thermal driver, conversion and transition) are rich in ${ }^{235} U$ and ${ }^{238} U$. Even if the targeted fast spectrum is well reproduced, the neutronics characteristics in the core center could be impacted through the indirect contribution. Then, this study has to be completed by sensitivity studies to nuclear data.

For this purpose, sensitivity coefficients are used, as mentioned above. For a parameter $\mathrm{P}$, it consists of evaluating by how much this parameter $\mathrm{P}$ is changed when another parameter $\mathrm{Q}$ is changed. Mathematically, it corresponds to $S_{P}=\frac{\partial P}{\partial Q}$. Relative sensitivity is also used, which is defined by $\tilde{S}_{P}=\frac{\partial P / P}{\partial Q / Q}$. Sensitivity coefficients become sensitivity vector coefficient to 
cover the N isotopes of interest: $\vec{S}_{P}=\left(\begin{array}{c}\frac{\partial P}{\partial \Sigma_{1}} \\ \vdots \\ \frac{\partial P}{\partial \Sigma_{N}}\end{array}\right)$. Naturally, a similar definition is obtained for relative sensitivity coefficients, which leads to $\overrightarrow{\tilde{S}}_{P}$.

\subsection{Representativeness coefficient: evaluation of the indirect terms}

Such vectors are not easy to use and to compare. In 1980, ORLOV proposed the representativeness coefficient (Orlov, 1980), defined between a Reference core Ref and the Experimental core Exp. In our studies, Ref stands for the fast reference configuration whereas Exp stands for the optimized fast-thermal coupled core. Mathematically, the representativity factor is defined through sensitivities by:

$$
r_{P}=\frac{{ }^{t}\left(\overrightarrow{\tilde{S}}_{P}\right)_{R E F} M\left(\overrightarrow{\tilde{S}}_{P}\right)_{E X P}}{\sqrt{\int^{t}\left(\overrightarrow{\tilde{S}}_{P}\right)_{R E F} M\left(\overrightarrow{\tilde{S}}_{P}\right)_{R E F}} \sqrt{t^{t}\left(\overrightarrow{\tilde{S}}_{P}\right)_{E X P} M\left(\overrightarrow{\tilde{S}}_{P}\right)_{E X P}}}
$$

where $\mathrm{M}$ represents the variance-covariance matrix related to the isotopes of interest used in the sensitivity vector. Then, representativity, also called representativeness, is a correlation coefficient that represents the amount of information transposable from the Experimental to the Reference configurations.

Here, we present representativity factors calculations of several spectral indices used previously, taking into account all the important isotopes for the calculation of the sensitivity coefficients and the variance-covariance matrix from COMAC-V1 (Archier, 2014). Besides, only the indirect term $\left\langle\frac{\sigma_{n}}{\left\langle\sigma_{n} ; \Phi\right\rangle}-\frac{\sigma_{d}}{\left\langle\sigma_{d} ; \Phi\right\rangle} ; \delta \Phi\right\rangle$ is evaluated, which is the key point of the dependence to peripheral zones.

\begin{tabular}{|c|c|}
\hline Spectral indices & Representativeness coefficient \\
\hline$\tau_{f}\left({ }^{238} U\right) / \tau_{f}\left({ }^{235} U\right)$ & 0,989 \\
\hline$\tau_{f}\left({ }^{237} N p\right) / \tau_{f}\left({ }^{235} U\right)$ & 0,988 \\
\hline$\tau_{C}\left({ }^{238} U\right) / \tau_{f}\left({ }^{235} U\right)$ & 0,992 \\
\hline$\tau_{A}\left({ }^{10} B\right) / \tau_{f}\left({ }^{235} U\right)$ & 0,982 \\
\hline
\end{tabular}

Table 10: Representativeness coefficient for spectral indices 
These reactivity coefficients, close to 1 , mean that the central fast spectrum in the optimized coupled core is negligibly sensitive to peripheral elements, particularly uranium isotopes, through their cross-sections and related uncertainties.

Note: We could have calculated representativity coefficients of the reactivity effects of samples $\left(\Delta \rho_{\text {sample }}\right)$ to nuclear data but for very small reactivity effects the ECCO/ERANOS system of codes is not entirely trustable. Indeed, the procedure used is based on an equivalent generalized perturbation method and results from a compensation of compensations between terms of close magnitudes and opposite signs.

Then, in order to evaluate the dependence to peripheral isotopes for reactivity effects, the exact formulation of the standard perturbation theory is used.

\subsection{Reactivity effect due to insertion of samples: influence of peripheral zones}

From the transport equation: $\mathrm{L} \Phi=\left(\mathrm{T}+\frac{1}{\mathrm{k}} \mathrm{F}\right) \Phi$, a sample inserted in the core locally perturbs the flux and the three operators L, T and F. Noting with index PERT the perturbed values, the exact perturbation theory gives the variation of reactivity :

$$
\Delta \rho=\frac{\left\langle\Phi_{\mathrm{REF}}^{+} ;\left(-\Delta \mathrm{L}+\Delta \mathrm{T}+\frac{\Delta \mathrm{P}}{\mathrm{k}_{\mathrm{REF}}}\right) \Phi_{\mathrm{PERT}}\right\rangle}{\left\langle\Phi_{\mathrm{REF}}^{+} ; \mathrm{P}_{\mathrm{PERT}} \Phi_{\mathrm{PERT}}\right\rangle}=\frac{\left\langle\Phi_{\mathrm{REF}}^{+} ;\left(-\Delta \mathrm{L}+\Delta \mathrm{T}+\frac{\Delta \mathrm{P}}{\mathrm{k}_{\mathrm{PERT}}}\right) \Phi_{\mathrm{PERT}}\right\rangle}{\left\langle\Phi_{\mathrm{REF}}^{+} ; \mathrm{P}_{\mathrm{REF}} \Phi_{\mathrm{PERT}}\right\rangle}
$$

The reactivity effect due to the insertion of the sample is decomposed by reaction, isotopes and energy groups. Such information is essential to determine what the measurement would actual be. Practically, the module 'EXACT_SPT' from ERANOS is used, which is based on the second formulation of $\Delta \rho$.

The insertion of ${ }^{238,239} \mathrm{Pu},{ }^{235} \mathrm{U},{ }^{10} \mathrm{~B}$ and ${ }^{103} \mathrm{Rh}$ isotopes is simulated because of their interest for the GEN-IV reactors and their sensitivity profiles which cover the whole energy range. Practically, it represents centered cylinders $(\mathrm{r}=2 \mathrm{~cm}$ and $\mathrm{H}=20 \mathrm{~cm})$. The induced modifications of the total forward and adjoint fluxes are illustrated through radial profiles, as well as the decomposition of each reactivity effects on the influent isotopes and the 33 energy groups:

- Radial modification of the total forward flux due to the central sample 


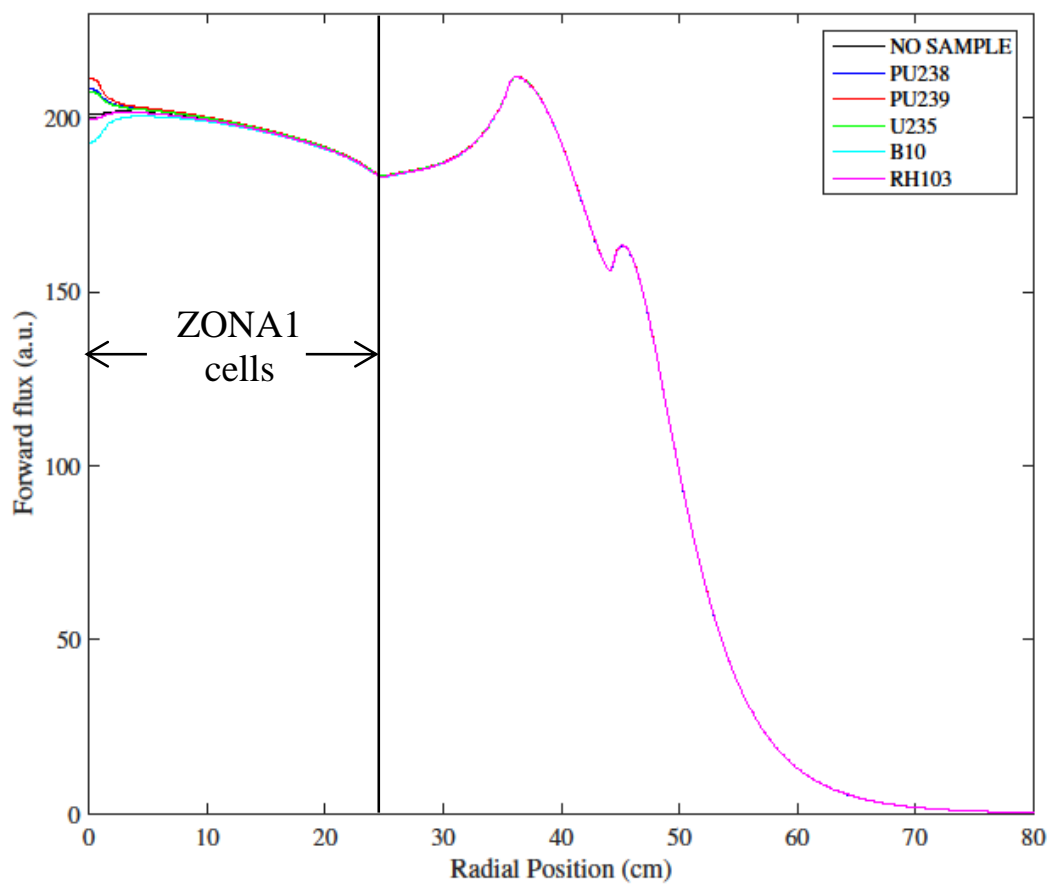

Figure 9 : Radial profile of the total forward flux

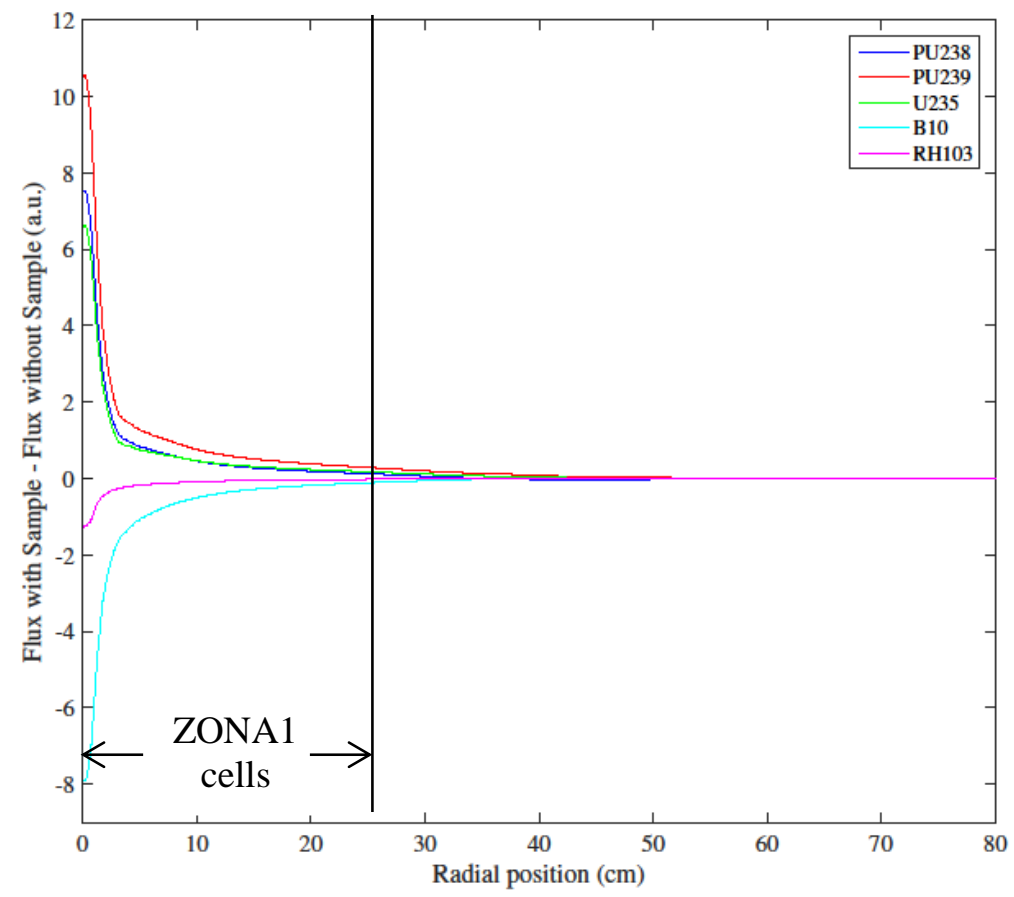

Figure 10 : Radial profile of the forward flux - Difference due to central samples

- Radial modification of the total adjoint flux due to the central sample 


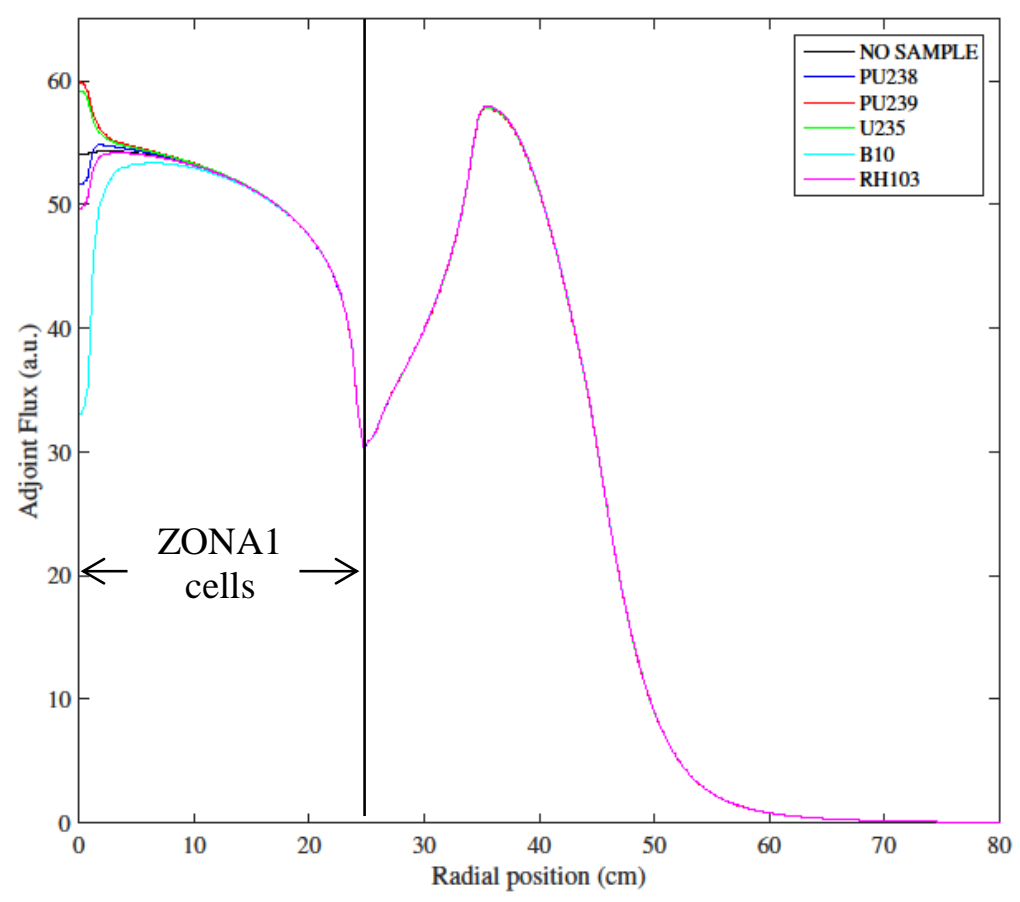

Figure 11 : Radial profile of the total adjoint flux

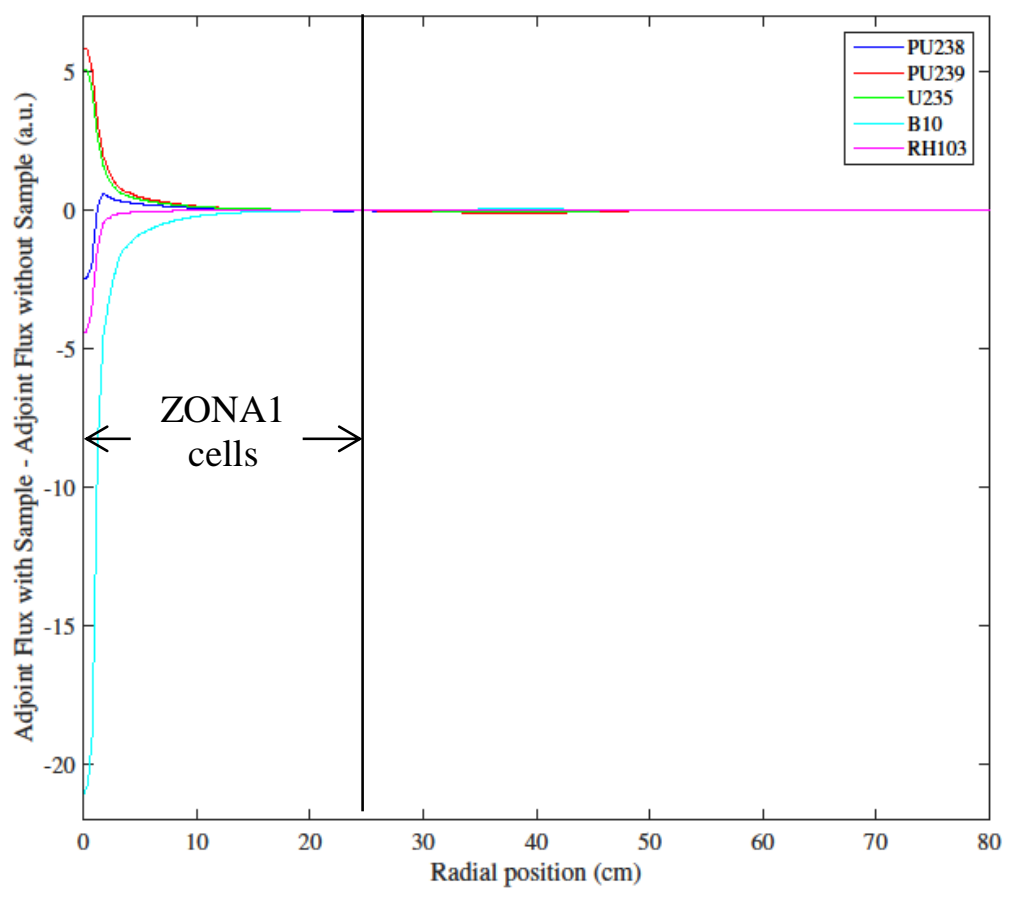

Figure 12 : Radial profile of the adjoint flux - Difference due to central samples

Even for these significant reactivity effects (see the following Tables 11 to 16), both adjoint and forward fluxes are not significantly modified by the central samples out of the ZONA1 
zone cells. Moreover, the modification of the adjoint flux is less spatially extended than the modification of the forward flux.

- Decomposition of the reactivity effects by isotopes and by reactions (in $10^{-5} \mathrm{Ak} / \mathrm{k}$ )

\begin{tabular}{|c|c|c|c|c|c|c|c|c|c|c|}
\hline \multirow[t]{2}{*}{ ISOTOPE } & \multicolumn{2}{|c|}{ CAPTURE } & \multicolumn{2}{|c|}{ FISSION } & \multicolumn{2}{|c|}{ ELASTIC } & \multicolumn{2}{|c|}{ INELASTIC } & \multicolumn{2}{|c|}{ SUM } \\
\hline & REF & C. Core & REF & C. Core & REF & C. Core & REF & C. Core & REF & C. Core \\
\hline${ }^{235} \mathrm{U}$ & $4.15 \mathrm{E}-17$ & $2.20 \mathrm{E}-17$ & $-1.69 \mathrm{E}-16$ & $-1.09 \mathrm{E}-16$ & $-5.00 \mathrm{E}-19$ & $2.73 \mathrm{E}-19$ & $1.68 \mathrm{E}-18$ & $1.06 \mathrm{E}-18$ & $-1.29 \mathrm{E}-16$ & $-8.70 \mathrm{E}-17$ \\
\hline${ }^{238} U$ & $2.37 \mathrm{E}-17$ & $1.24 \mathrm{E}-17$ & $-1.57 \mathrm{E}-18$ & $-3.20 \mathrm{E}-18$ & $-9.51 \mathrm{E}-19$ & $1.05 \mathrm{E}-19$ & $-2.96 \mathrm{E}-19$ & $-8.38 \mathrm{E}-20$ & $1.50 \mathrm{E}-17$ & $5.50 \mathrm{E}-18$ \\
\hline${ }^{238} \mathrm{Pu}$ & $-2.70 \mathrm{E}-05$ & $-1.65 \mathrm{E}-05$ & $2.47 \mathrm{E}-04$ & $1.60 \mathrm{E}-04$ & $-6.46 \mathrm{E}-08$ & $-8.12 \mathrm{E}-08$ & $-2.22 \mathrm{E}-06$ & $-1.68 \mathrm{E}-06$ & $2.18 \mathrm{E}-04$ & $1.42 \mathrm{E}-04$ \\
\hline${ }^{239} \mathrm{Pu}$ & $6.72 \mathrm{E}-17$ & 4.03E-17 & $-8.57 \mathrm{E}-17$ & $-7.18 \mathrm{E}-17$ & $-5.79 \mathrm{E}-19$ & $2.58 \mathrm{E}-19$ & $-3.86 \mathrm{E}-19$ & $1.36 \mathrm{E}-20$ & $-2.02 \mathrm{E}-17$ & $-3.17 \mathrm{E}-17$ \\
\hline${ }^{240} \mathrm{Pu}$ & $8.48 \mathrm{E}-17$ & $1.70 \mathrm{E}-16$ & $1.15 \mathrm{E}-16$ & $4.85 \mathrm{E}-17$ & $-1.59 \mathrm{E}-18$ & $-4.19 \mathrm{E}-19$ & $2.47 \mathrm{E}-18$ & $1.85 \mathrm{E}-18$ & $1.99 \mathrm{E}-16$ & $2.19 \mathrm{E}-16$ \\
\hline${ }^{241} \mathrm{Pu}$ & $3.21 \mathrm{E}-17$ & $1.68 \mathrm{E}-17$ & $-2.68 \mathrm{E}-16$ & $-1.68 \mathrm{E}-16$ & $-4.21 \mathrm{E}-19$ & $2.73 \mathrm{E}-19$ & $-1.68 \mathrm{E}-18$ & $-1.11 \mathrm{E}-18$ & $-2.40 \mathrm{E}-16$ & $-1.54 \mathrm{E}-16$ \\
\hline${ }^{242} \mathrm{Pu}$ & $5.03 \mathrm{E}-17$ & $4.50 \mathrm{E}-17$ & $1.06 \mathrm{E}-16$ & $4.36 \mathrm{E}-17$ & $-2.26 \mathrm{E}-18$ & $-7.90 \mathrm{E}-19$ & $3.22 \mathrm{E}-18$ & $2.58 \mathrm{E}-18$ & $1.54 \mathrm{E}-16$ & $8.88 \mathrm{E}-17$ \\
\hline${ }^{241} \mathrm{Am}$ & $1.65 \mathrm{E}-16$ & $1.01 \mathrm{E}-16$ & $1.37 \mathrm{E}-16$ & $6.25 \mathrm{E}-17$ & $-2.63 \mathrm{E}-19$ & 4.79E-19 & 3.34E-18 & $2.16 \mathrm{E}-18$ & 3.05E-16 & $1.66 \mathrm{E}-16$ \\
\hline${ }^{16} \mathrm{O}$ & $4.52 \mathrm{E}-12$ & $2.97 \mathrm{E}-12$ & $0.00 \mathrm{E}+00$ & $0.00 \mathrm{E}+00$ & $7.23 \mathrm{E}-11$ & $7.26 \mathrm{E}-11$ & $5.22 \mathrm{E}-12$ & $3.60 \mathrm{E}-12$ & $8.59 \mathrm{E}-11$ & $8.19 \mathrm{E}-11$ \\
\hline $\mathrm{H}$ & 2.19E-20 & $1.34 \mathrm{E}-20$ & $0.00 \mathrm{E}+00$ & $0.00 \mathrm{E}+00$ & $-5.80 \mathrm{E}-17$ & $-2.76 \mathrm{E}-17$ & $0.00 \mathrm{E}+00$ & $0.00 \mathrm{E}+00$ & $-5.80 \mathrm{E}-17$ & $-2.75 \mathrm{E}-17$ \\
\hline${ }^{14} \mathrm{~N}$ & $-8.49 \mathrm{E}-10$ & $-5.11 \mathrm{E}-10$ & $0.00 \mathrm{E}+00$ & $0.00 \mathrm{E}+00$ & $-2.92 \mathrm{E}-10$ & $-6.57 \mathrm{E}-11$ & 4.97E-12 & $3.61 \mathrm{E}-12$ & $-1.13 \mathrm{E}-09$ & $-5.69 \mathrm{E}-10$ \\
\hline${ }^{10} \mathrm{~B}$ & 2.64E-16 & $1.56 \mathrm{E}-16$ & $0.00 \mathrm{E}+00$ & $0.00 \mathrm{E}+00$ & $1.20 \mathrm{E}-17$ & $9.87 \mathrm{E}-18$ & $7.99 \mathrm{E}-20$ & $7.59 \mathrm{E}-20$ & $2.76 \mathrm{E}-16$ & $1.66 \mathrm{E}-16$ \\
\hline${ }^{11} \mathrm{~B}$ & $9.15 \mathrm{E}-20$ & 6.07E-20 & $0.00 \mathrm{E}+00$ & $0.00 \mathrm{E}+00$ & $6.61 \mathrm{E}-18$ & $7.75 \mathrm{E}-18$ & $-1.36 \mathrm{E}-19$ & $-6.99 \mathrm{E}-20$ & $6.51 \mathrm{E}-18$ & $7.71 \mathrm{E}-18$ \\
\hline${ }^{27} \mathrm{Al}$ & $2.45 \mathrm{E}-18$ & $1.55 \mathrm{E}-18$ & $0.00 \mathrm{E}+00$ & $0.00 \mathrm{E}+00$ & $1.20 \mathrm{E}-17$ & $9.22 \mathrm{E}-18$ & $-2.72 \mathrm{E}-18$ & $-1.79 \mathrm{E}-18$ & $1.16 \mathrm{E}-17$ & $8.93 \mathrm{E}-18$ \\
\hline${ }^{26} \mathrm{Fe}$ & $-6.40 \mathrm{E}-18$ & $-4.21 \mathrm{E}-18$ & $0.00 \mathrm{E}+00$ & $0.00 \mathrm{E}+00$ & 3.07E-19 & $6.86 \mathrm{E}-19$ & $-1.97 \mathrm{E}-18$ & $-1.43 \mathrm{E}-18$ & $-8.41 \mathrm{E}-18$ & $-5.15 \mathrm{E}-18$ \\
\hline${ }^{103} \mathrm{Rh}$ & $-3.63 \mathrm{E}-22$ & $-2.98 \mathrm{E}-22$ & $0.00 \mathrm{E}+00$ & $0.00 \mathrm{E}+00$ & $2.70 \mathrm{E}-18$ & $2.68 \mathrm{E}-18$ & $2.63 \mathrm{E}-26$ & $2.24 \mathrm{E}-26$ & $2.70 \mathrm{E}-18$ & $2.69 \mathrm{E}-18$ \\
\hline $\begin{array}{c}\text { PART } \\
>0\end{array}$ & $4.53 \mathrm{E}-12$ & $2.97 \mathrm{E}-12$ & $2.47 \mathrm{E}-04$ & $1.60 \mathrm{E}-04$ & 7.23E-11 & $7.26 \mathrm{E}-11$ & $1.02 \mathrm{E}-11$ & $7.21 \mathrm{E}-12$ & $2.47 \mathrm{E}-04$ & $1.60 \mathrm{E}-04$ \\
\hline $\begin{array}{c}\text { PART } \\
<0\end{array}$ & $-2.70 \mathrm{E}-05$ & $-1.65 \mathrm{E}-05$ & $-5.25 \mathrm{E}-16$ & $-3.52 \mathrm{E}-16$ & $-6.49 \mathrm{E}-08$ & $-8.12 \mathrm{E}-08$ & $-2.22 \mathrm{E}-06$ & $-1.68 \mathrm{E}-06$ & $-2.93 \mathrm{E}-05$ & $-1.83 \mathrm{E}-05$ \\
\hline SUM & $-2.70 \mathrm{E}-05$ & $-1.65 \mathrm{E}-05$ & 2.47E-04 & $1.60 \mathrm{E}-04$ & $-6.48 \mathrm{E}-08$ & $-8.12 \mathrm{E}-08$ & $-2.22 \mathrm{E}-06$ & $-1.68 \mathrm{E}-06$ & $2.18 \mathrm{E}-04$ & $1.42 \mathrm{E}-04$ \\
\hline
\end{tabular}

Table 11 : Decomposition of the reactivity effect by isotopes and by reactions due to ${ }^{238} \mathbf{P u}$ sample in the central oscillation channel

\begin{tabular}{|c|c|c|c|c|c|c|c|c|c|c|}
\hline \multirow{2}{*}{ ISOTOPE } & \multicolumn{2}{|c|}{ CAPTURE } & \multicolumn{2}{c|}{ FISSION } & \multicolumn{2}{c|}{ ELASTIC } & \multicolumn{2}{c|}{ INELASTIC } & \multicolumn{2}{c|}{ SUM } \\
\hline & REF & C. Core & REF & C. Core & REF & C. Core & REF & C. Core & REF & C. Core \\
\hline${ }^{235} \mathrm{U}$ & $5.20 \mathrm{E}-17$ & $2.98 \mathrm{E}-17$ & $-2.04 \mathrm{E}-16$ & $-1.34 \mathrm{E}-16$ & $-4.30 \mathrm{E}-19$ & $4.43 \mathrm{E}-19$ & $1.81 \mathrm{E}-18$ & $1.10 \mathrm{E}-18$ & $-1.53 \mathrm{E}-16$ & $-1.04 \mathrm{E}-16$ \\
\hline${ }^{238} \mathrm{U}$ & $1.22 \mathrm{E}-17$ & $4.38 \mathrm{E}-18$ & $1.46 \mathrm{E}-18$ & $-1.64 \mathrm{E}-18$ & $-9.68 \mathrm{E}-19$ & $2.61 \mathrm{E}-19$ & $-2.58 \mathrm{E}-19$ & $-2.91 \mathrm{E}-19$ & $6.16 \mathrm{E}-18$ & $-1.63 \mathrm{E}-18$ \\
\hline${ }^{238} \mathrm{Pu}$ & $7.95 \mathrm{E}-17$ & $4.53 \mathrm{E}-17$ & $1.21 \mathrm{E}-16$ & $5.51 \mathrm{E}-17$ & $-6.99 \mathrm{E}-19$ & $3.34 \mathrm{E}-19$ & $-9.58 \mathrm{E}-19$ & $-4.13 \mathrm{E}-19$ & $1.97 \mathrm{E}-16$ & $9.86 \mathrm{E}-17$ \\
\hline${ }^{239} \mathrm{Pu}$ & $-2.62 \mathrm{E}-05$ & $-1.58 \mathrm{E}-05$ & $3.36 \mathrm{E}-04$ & $2.22 \mathrm{E}-04$ & $-3.99 \mathrm{E}-08$ & $-6.40 \mathrm{E}-08$ & $-2.40 \mathrm{E}-06$ & $-1.91 \mathrm{E}-06$ & $3.08 \mathrm{E}-04$ & $2.04 \mathrm{E}-04$ \\
\hline${ }^{240} \mathrm{Pu}$ & $8.08 \mathrm{E}-17$ & $1.49 \mathrm{E}-16$ & $1.21 \mathrm{E}-16$ & $5.34 \mathrm{E}-17$ & $-1.84 \mathrm{E}-18$ & $-4.12 \mathrm{E}-19$ & $2.57 \mathrm{E}-18$ & $1.89 \mathrm{E}-18$ & $2.01 \mathrm{E}-16$ & $2.03 \mathrm{E}-16$ \\
\hline${ }^{241} \mathrm{Pu}$ & $4.89 \mathrm{E}-17$ & $2.87 \mathrm{E}-17$ & $-3.11 \mathrm{E}-16$ & $-1.99 \mathrm{E}-16$ & $-3.29 \mathrm{E}-19$ & $4.57 \mathrm{E}-19$ & $-1.92 \mathrm{E}-18$ & $-1.43 \mathrm{E}-18$ & $-2.67 \mathrm{E}-16$ & $-1.73 \mathrm{E}-16$ \\
\hline${ }^{242} \mathrm{Pu}$ & $7.07 \mathrm{E}-17$ & $4.45 \mathrm{E}-17$ & $1.11 \mathrm{E}-16$ & $4.78 \mathrm{E}-17$ & $-2.39 \mathrm{E}-18$ & $-6.73 \mathrm{E}-19$ & $3.16 \mathrm{E}-18$ & $2.43 \mathrm{E}-18$ & $1.80 \mathrm{E}-16$ & $9.22 \mathrm{E}-17$ \\
\hline${ }^{241} \mathrm{Am}$ & $1.92 \mathrm{E}-16$ & $1.12 \mathrm{E}-16$ & $1.43 \mathrm{E}-16$ & $6.83 \mathrm{E}-17$ & $-2.01 \mathrm{E}-19$ & $6.55 \mathrm{E}-19$ & $3.52 \mathrm{E}-18$ & $2.31 \mathrm{E}-18$ & $3.38 \mathrm{E}-16$ & $1.83 \mathrm{E}-16$ \\
\hline${ }^{16} \mathrm{O}$ & $4.60 \mathrm{E}-12$ & $3.38 \mathrm{E}-12$ & $0.00 \mathrm{E}+00$ & $0.00 \mathrm{E}+00$ & $8.66 \mathrm{E}-11$ & $8.91 \mathrm{E}-11$ & $5.68 \mathrm{E}-12$ & $4.33 \mathrm{E}-12$ & $1.01 \mathrm{E}-10$ & $1.01 \mathrm{E}-10$ \\
\hline $\mathrm{H}$ & $2.47 \mathrm{E}-20$ & $1.47 \mathrm{E}-20$ & $0.00 \mathrm{E}+00$ & $0.00 \mathrm{E}+00$ & $-6.16 \mathrm{E}-17$ & $-2.67 \mathrm{E}-17$ & $0.00 \mathrm{E}+00$ & $0.00 \mathrm{E}+00$ & $-6.16 \mathrm{E}-17$ & $-2.67 \mathrm{E}-17$ \\
\hline${ }^{14} \mathrm{~N}$ & $-8.80 \mathrm{E}-10$ & $-5.74 \mathrm{E}-10$ & $0.00 \mathrm{E}+00$ & $0.00 \mathrm{E}+00$ & $-2.73 \mathrm{E}-10$ & $-1.45 \mathrm{E}-11$ & $5.14 \mathrm{E}-12$ & $4.16 \mathrm{E}-12$ & $-1.14 \mathrm{E}-09$ & $-5.78 \mathrm{E}-10$ \\
\hline${ }^{10} \mathrm{~B}$ & $2.98 \mathrm{E}-16$ & $1.71 \mathrm{E}-16$ & $0.00 \mathrm{E}+00$ & $0.00 \mathrm{E}+00$ & $1.35 \mathrm{E}-17$ & $1.17 \mathrm{E}-17$ & $6.17 \mathrm{E}-20$ & $7.27 \mathrm{E}-20$ & $3.11 \mathrm{E}-16$ & $1.83 \mathrm{E}-16$ \\
\hline${ }^{11} \mathrm{~B}$ & $9.60 \mathrm{E}-20$ & $6.99 \mathrm{E}-20$ & $0.00 \mathrm{E}+00$ & $0.00 \mathrm{E}+00$ & $8.53 \mathrm{E}-18$ & $1.01 \mathrm{E}-17$ & $-1.42 \mathrm{E}-19$ & $-7.77 \mathrm{E}-20$ & $8.42 \mathrm{E}-18$ & $1.00 \mathrm{E}-17$ \\
\hline
\end{tabular}




\begin{tabular}{|c|c|c|c|c|c|c|c|c|c|c|}
${ }^{27} \mathrm{Al}$ & $2.67 \mathrm{E}-18$ & $1.76 \mathrm{E}-18$ & $0.00 \mathrm{E}+00$ & $0.00 \mathrm{E}+00$ & $1.29 \mathrm{E}-17$ & $1.04 \mathrm{E}-17$ & $-2.79 \mathrm{E}-18$ & $-1.99 \mathrm{E}-18$ & $1.27 \mathrm{E}-17$ & $1.01 \mathrm{E}-17$ \\
\hline${ }^{26} \mathrm{Fe}$ & $-2.96 \mathrm{E}-18$ & $-1.77 \mathrm{E}-18$ & $0.00 \mathrm{E}+00$ & $0.00 \mathrm{E}+00$ & $1.74 \mathrm{E}-19$ & $8.77 \mathrm{E}-19$ & $-1.99 \mathrm{E}-18$ & $-1.54 \mathrm{E}-18$ & $-5.12 \mathrm{E}-18$ & $-2.65 \mathrm{E}-18$ \\
\hline${ }^{103} \mathrm{Rh}$ & $-3.63 \mathrm{E}-22$ & $-2.74 \mathrm{E}-22$ & $0.00 \mathrm{E}+00$ & $0.00 \mathrm{E}+00$ & $3.32 \mathrm{E}-18$ & $3.42 \mathrm{E}-18$ & $2.63 \mathrm{E}-26$ & $2.32 \mathrm{E}-26$ & $3.32 \mathrm{E}-18$ & $3.42 \mathrm{E}-18$ \\
\hline $\begin{array}{c}\text { PART } \\
>0\end{array}$ & $4.60 \mathrm{E}-12$ & $3.39 \mathrm{E}-12$ & $3.36 \mathrm{E}-04$ & $2.22 \mathrm{E}-04$ & $8.66 \mathrm{E}-11$ & $8.91 \mathrm{E}-11$ & $1.08 \mathrm{E}-11$ & $8.49 \mathrm{E}-12$ & $3.37 \mathrm{E}-04$ & $2.22 \mathrm{E}-04$ \\
\hline $\begin{array}{c}\text { PART } \\
<0\end{array}$ & $-2.62 \mathrm{E}-05$ & $-1.58 \mathrm{E}-05$ & $-5.15 \mathrm{E}-16$ & $-3.34 \mathrm{E}-16$ & $-4.02 \mathrm{E}-08$ & $-6.40 \mathrm{E}-08$ & $-2.40 \mathrm{E}-06$ & $-1.91 \mathrm{E}-06$ & $-2.86 \mathrm{E}-05$ & $-1.77 \mathrm{E}-05$ \\
\hline SUM & $-2.62 \mathrm{E}-05$ & $-1.58 \mathrm{E}-05$ & $3.36 \mathrm{E}-04$ & $2.22 \mathrm{E}-04$ & $-4.01 \mathrm{E}-08$ & $-6.39 \mathrm{E}-08$ & $-2.40 \mathrm{E}-06$ & $-1.91 \mathrm{E}-06$ & $3.08 \mathrm{E}-04$ & $2.04 \mathrm{E}-04$ \\
\hline
\end{tabular}

Table 12 : Decomposition of the reactivity effect by isotopes and by reactions due to a ${ }^{239} \mathrm{Pu}$ sample in the central oscillation channel

\begin{tabular}{|c|c|c|c|c|c|c|c|c|c|c|}
\hline \multirow[t]{2}{*}{ ISOTOPE } & \multicolumn{2}{|c|}{ CAPTURE } & \multicolumn{2}{|c|}{ FISSION } & \multicolumn{2}{|c|}{ ELASTIC } & \multicolumn{2}{|c|}{ INELASTIC } & \multicolumn{2}{|c|}{ SUM } \\
\hline & REF & C. Core & REF & C. Core & REF & C. Core & REF & C. Core & REF & C. Core \\
\hline${ }^{235} \mathrm{U}$ & $-3.42 \mathrm{E}-05$ & $-2.11 \mathrm{E}-05$ & $2.50 \mathrm{E}-04$ & $1.64 \mathrm{E}-04$ & $-4.51 \mathrm{E}-08$ & $-6.33 \mathrm{E}-08$ & $-4.84 \mathrm{E}-06$ & $-3.67 \mathrm{E}-06$ & $2.11 \mathrm{E}-04$ & $1.40 \mathrm{E}-04$ \\
\hline${ }^{238} \mathrm{U}$ & $4.76 \mathrm{E}-18$ & $-4.81 \mathrm{E}-18$ & $-4.69 E-18$ & $-5.27 \mathrm{E}-18$ & $-1.28 \mathrm{E}-18$ & $-1.22 \mathrm{E}-19$ & $-8.05 \mathrm{E}-19$ & $-4.10 \mathrm{E}-19$ & $-8.72 \mathrm{E}-18$ & $-1.48 \mathrm{E}-17$ \\
\hline${ }^{238} \mathrm{Pu}$ & $8.49 \mathrm{E}-17$ & $5.88 \mathrm{E}-17$ & $8.17 \mathrm{E}-17$ & $2.93 \mathrm{E}-17$ & $-1.05 \mathrm{E}-18$ & $-6.44 \mathrm{E}-20$ & $-1.21 \mathrm{E}-18$ & $-4.59 \mathrm{E}-19$ & $1.62 \mathrm{E}-16$ & $8.60 \mathrm{E}-17$ \\
\hline${ }^{239} \mathrm{Pu}$ & $6.09 \mathrm{E}-17$ & $3.76 \mathrm{E}-17$ & $-9.05 \mathrm{E}-17$ & $-7.40 \mathrm{E}-17$ & $-9.18 \mathrm{E}-19$ & $1.70 \mathrm{E}-20$ & $-7.63 \mathrm{E}-19$ & $-2.77 \mathrm{E}-19$ & $-3.20 \mathrm{E}-17$ & $-3.72 \mathrm{E}-17$ \\
\hline${ }^{240} \mathrm{Pu}$ & $5.44 \mathrm{E}-17$ & $1.30 \mathrm{E}-16$ & $8.46 \mathrm{E}-17$ & $2.85 \mathrm{E}-17$ & $-2.23 \mathrm{E}-18$ & $-8.91 \mathrm{E}-19$ & 2.03E-18 & $1.50 \mathrm{E}-18$ & $1.37 \mathrm{E}-16$ & $1.58 \mathrm{E}-16$ \\
\hline${ }^{241} \mathrm{Pu}$ & $3.86 \mathrm{E}-17$ & $2.21 \mathrm{E}-17$ & $-2.90 \mathrm{E}-16$ & $-1.85 \mathrm{E}-16$ & $-7.02 \mathrm{E}-19$ & 7.82E-20 & $-1.99 \mathrm{E}-18$ & $-1.34 \mathrm{E}-18$ & $-2.57 \mathrm{E}-16$ & $-1.66 \mathrm{E}-16$ \\
\hline${ }^{242} \mathrm{Pu}$ & $6.09 \mathrm{E}-17$ & $4.09 \mathrm{E}-17$ & $7.55 \mathrm{E}-17$ & $2.37 \mathrm{E}-17$ & $-2.48 \mathrm{E}-18$ & $-9.52 \mathrm{E}-19$ & $2.09 \mathrm{E}-18$ & $1.68 \mathrm{E}-18$ & $1.33 \mathrm{E}-16$ & $6.36 \mathrm{E}-17$ \\
\hline${ }^{241} \mathrm{Am}$ & $1.62 \mathrm{E}-16$ & $9.46 \mathrm{E}-17$ & $9.21 \mathrm{E}-17$ & $3.30 \mathrm{E}-17$ & $-5.53 \mathrm{E}-19$ & $2.78 \mathrm{E}-19$ & $2.38 \mathrm{E}-18$ & $1.33 \mathrm{E}-18$ & $2.55 \mathrm{E}-16$ & $1.29 \mathrm{E}-16$ \\
\hline${ }^{16} \mathrm{O}$ & $5.08 \mathrm{E}-12$ & $3.34 \mathrm{E}-12$ & $0.00 \mathrm{E}+00$ & $0.00 \mathrm{E}+00$ & $5.51 \mathrm{E}-11$ & $5.91 \mathrm{E}-11$ & $6.23 \mathrm{E}-12$ & $4.30 \mathrm{E}-12$ & $7.11 \mathrm{E}-11$ & $7.01 \mathrm{E}-11$ \\
\hline $\mathrm{H}$ & $2.24 \mathrm{E}-20$ & $1.37 \mathrm{E}-20$ & $0.00 \mathrm{E}+00$ & $0.00 \mathrm{E}+00$ & $-6.33 \mathrm{E}-17$ & $-3.17 \mathrm{E}-17$ & $0.00 \mathrm{E}+00$ & $0.00 \mathrm{E}+00$ & $-6.33 \mathrm{E}-17$ & $-3.17 \mathrm{E}-17$ \\
\hline${ }^{14} \mathrm{~N}$ & $-8.75 \mathrm{E}-10$ & $-5.28 \mathrm{E}-10$ & $0.00 \mathrm{E}+00$ & $0.00 \mathrm{E}+00$ & $-3.37 \mathrm{E}-10$ & $-1.02 \mathrm{E}-10$ & $5.75 \mathrm{E}-12$ & $4.16 \mathrm{E}-12$ & $-1.20 \mathrm{E}-09$ & $-6.20 \mathrm{E}-10$ \\
\hline${ }^{10} \mathrm{~B}$ & $2.62 \mathrm{E}-16$ & $1.55 \mathrm{E}-16$ & $0.00 \mathrm{E}+00$ & $0.00 \mathrm{E}+00$ & $1.06 \mathrm{E}-17$ & $8.65 \mathrm{E}-18$ & $1.18 \mathrm{E}-19$ & $1.03 \mathrm{E}-19$ & $2.73 \mathrm{E}-16$ & $1.63 \mathrm{E}-16$ \\
\hline${ }^{11} \mathrm{~B}$ & $9.16 \mathrm{E}-20$ & $6.13 \mathrm{E}-20$ & $0.00 \mathrm{E}+00$ & $0.00 \mathrm{E}+00$ & $5.55 \mathrm{E}-18$ & $6.81 \mathrm{E}-18$ & $-1.29 \mathrm{E}-19$ & $-6.37 \mathrm{E}-20$ & $5.44 \mathrm{E}-18$ & $6.77 \mathrm{E}-18$ \\
\hline${ }^{27} \mathrm{Al}$ & $3.01 \mathrm{E}-18$ & $1.90 \mathrm{E}-18$ & $0.00 \mathrm{E}+00$ & $0.00 \mathrm{E}+00$ & $1.05 \mathrm{E}-17$ & $8.02 \mathrm{E}-18$ & $-2.73 \mathrm{E}-18$ & $-1.78 \mathrm{E}-18$ & $1.07 \mathrm{E}-17$ & $8.08 \mathrm{E}-18$ \\
\hline${ }^{26} \mathrm{Fe}$ & $-4.47 \mathrm{E}-18$ & $-2.94 \mathrm{E}-18$ & $0.00 \mathrm{E}+00$ & $0.00 \mathrm{E}+00$ & $-4.13 \mathrm{E}-19$ & $1.38 \mathrm{E}-19$ & $-1.89 \mathrm{E}-18$ & $-1.38 \mathrm{E}-18$ & $-7.06 \mathrm{E}-18$ & $-4.36 \mathrm{E}-18$ \\
\hline${ }^{103} \mathrm{Rh}$ & $-3.13 \mathrm{E}-22$ & $-2.57 \mathrm{E}-22$ & $0.00 \mathrm{E}+00$ & $0.00 \mathrm{E}+00$ & $2.11 \mathrm{E}-18$ & $2.27 \mathrm{E}-18$ & $2.67 \mathrm{E}-26$ & $2.27 \mathrm{E}-26$ & $2.11 \mathrm{E}-18$ & $2.28 \mathrm{E}-18$ \\
\hline $\begin{array}{c}\text { PART } \\
>0\end{array}$ & $5.08 \mathrm{E}-12$ & $3.34 \mathrm{E}-12$ & $2.50 \mathrm{E}-04$ & $1.64 \mathrm{E}-04$ & $5.51 \mathrm{E}-11$ & $5.91 \mathrm{E}-11$ & $1.20 \mathrm{E}-11$ & $8.46 \mathrm{E}-12$ & $2.50 \mathrm{E}-04$ & $1.65 \mathrm{E}-04$ \\
\hline $\begin{array}{c}\text { PART } \\
<0\end{array}$ & $-3.42 \mathrm{E}-05$ & $-2.11 \mathrm{E}-05$ & $-3.85 \mathrm{E}-16$ & $-2.64 \mathrm{E}-16$ & $-4.54 \mathrm{E}-08$ & $-6.34 \mathrm{E}-08$ & $-4.84 \mathrm{E}-06$ & $-3.67 \mathrm{E}-06$ & $-3.90 \mathrm{E}-05$ & $-2.48 \mathrm{E}-05$ \\
\hline SUM & $-3.42 \mathrm{E}-05$ & $-2.11 \mathrm{E}-05$ & $2.50 \mathrm{E}-04$ & $1.64 \mathrm{E}-04$ & $-4.54 \mathrm{E}-08$ & $-6.34 \mathrm{E}-08$ & $-4.84 \mathrm{E}-06$ & $-3.67 \mathrm{E}-06$ & $2.11 \mathrm{E}-04$ & $1.40 \mathrm{E}-04$ \\
\hline
\end{tabular}

Table 13 : Decomposition of the reactivity effect by isotopes and by reactions due to a ${ }^{235} \mathrm{U}$ sample in the central oscillation channel

\begin{tabular}{|c|c|c|c|c|c|c|c|c|c|c|}
\hline ISOTOPE & \multicolumn{2}{|c|}{ CAPTURE } & \multicolumn{2}{c|}{ FISSION } & \multicolumn{2}{c|}{ ELASTIC } & \multicolumn{2}{c|}{ INELASTIC } & \multicolumn{2}{c|}{ SUM } \\
\hline & REF & C. Core & REF & C. Core & REF & C. Core & REF & C. Core & REF & C. Core \\
\hline${ }^{235} \mathrm{U}$ & $2.65 \mathrm{E}-17$ & $1.56 \mathrm{E}-17$ & $-7.46 \mathrm{E}-17$ & $-4.79 \mathrm{E}-17$ & $7.91 \mathrm{E}-20$ & $1.56 \mathrm{E}-18$ & $3.45 \mathrm{E}-18$ & $3.07 \mathrm{E}-18$ & $-4.42 \mathrm{E}-17$ & $-2.73 \mathrm{E}-17$ \\
\hline${ }^{238} \mathrm{U}$ & $1.38 \mathrm{E}-17$ & $7.52 \mathrm{E}-18$ & $3.94 \mathrm{E}-18$ & $2.53 \mathrm{E}-18$ & $1.04 \mathrm{E}-19$ & $1.90 \mathrm{E}-18$ & $3.80 \mathrm{E}-18$ & $3.51 \mathrm{E}-18$ & $2.29 \mathrm{E}-17$ & $1.62 \mathrm{E}-17$ \\
\hline${ }^{238} \mathrm{Pu}$ & $3.68 \mathrm{E}-17$ & $2.16 \mathrm{E}-17$ & $7.81 \mathrm{E}-17$ & $6.54 \mathrm{E}-17$ & $2.18 \mathrm{E}-20$ & $1.74 \mathrm{E}-18$ & $-4.46 \mathrm{E}-20$ & $9.60 \mathrm{E}-19$ & $1.15 \mathrm{E}-16$ & $9.00 \mathrm{E}-17$ \\
\hline${ }^{239} \mathrm{Pu}$ & $3.03 \mathrm{E}-17$ & $1.51 \mathrm{E}-17$ & $-7.99 \mathrm{E}-19$ & $-4.84 \mathrm{E}-19$ & $4.95 \mathrm{E}-20$ & $1.65 \mathrm{E}-18$ & $1.08 \mathrm{E}-18$ & $1.56 \mathrm{E}-18$ & $3.08 \mathrm{E}-17$ & $1.79 \mathrm{E}-17$ \\
\hline${ }^{240} \mathrm{Pu}$ & $3.06 \mathrm{E}-17$ & $1.96 \mathrm{E}-17$ & $8.89 \mathrm{E}-17$ & $6.38 \mathrm{E}-17$ & $-3.91 \mathrm{E}-19$ & $1.61 \mathrm{E}-18$ & $3.61 \mathrm{E}-18$ & $3.31 \mathrm{E}-18$ & $1.23 \mathrm{E}-16$ & $8.86 \mathrm{E}-17$ \\
\hline${ }^{241} \mathrm{Pu}$ & $1.92 \mathrm{E}-17$ & $1.17 \mathrm{E}-17$ & $-1.28 \mathrm{E}-16$ & $-7.97 \mathrm{E}-17$ & $1.09 \mathrm{E}-19$ & $1.54 \mathrm{E}-18$ & $3.08 \mathrm{E}-19$ & $3.23 \mathrm{E}-19$ & $-1.07 \mathrm{E}-16$ & $-6.58 \mathrm{E}-17$ \\
\hline${ }^{242} \mathrm{Pu}$ & $3.02 \mathrm{E}-17$ & $1.72 \mathrm{E}-17$ & $8.98 \mathrm{E}-17$ & $6.24 \mathrm{E}-17$ & $-4.09 \mathrm{E}-19$ & $1.64 \mathrm{E}-18$ & $4.34 \mathrm{E}-18$ & $4.69 \mathrm{E}-18$ & $1.24 \mathrm{E}-16$ & $8.62 \mathrm{E}-17$ \\
\hline${ }^{241} \mathrm{Am}$ & $8.73 \mathrm{E}-17$ & $5.76 \mathrm{E}-17$ & $1.05 \mathrm{E}-16$ & $7.08 \mathrm{E}-17$ & $2.42 \mathrm{E}-19$ & $1.80 \mathrm{E}-18$ & $4.13 \mathrm{E}-18$ & $3.64 \mathrm{E}-18$ & $1.97 \mathrm{E}-16$ & $1.34 \mathrm{E}-16$ \\
\hline
\end{tabular}




\begin{tabular}{|c|c|c|c|c|c|c|c|c|c|c|}
${ }^{16} \mathrm{O}$ & $2.15 \mathrm{E}-12$ & $1.37 \mathrm{E}-12$ & $0.00 \mathrm{E}+00$ & $0.00 \mathrm{E}+00$ & $6.14 \mathrm{E}-11$ & $1.20 \mathrm{E}-10$ & $-1.44 \mathrm{E}-12$ & $-9.94 \mathrm{E}-13$ & $6.09 \mathrm{E}-11$ & $1.19 \mathrm{E}-10$ \\
\hline $\mathrm{H}$ & $1.12 \mathrm{E}-20$ & $6.37 \mathrm{E}-21$ & $0.00 \mathrm{E}+00$ & $0.00 \mathrm{E}+00$ & $-2.46 \mathrm{E}-17$ & $8.12 \mathrm{E}-18$ & $0.00 \mathrm{E}+00$ & $0.00 \mathrm{E}+00$ & $-2.45 \mathrm{E}-17$ & $8.16 \mathrm{E}-18$ \\
\hline${ }^{14} \mathrm{~N}$ & $-6.73 \mathrm{E}-10$ & $-4.45 \mathrm{E}-10$ & $0.00 \mathrm{E}+00$ & $0.00 \mathrm{E}+00$ & $1.35 \mathrm{E}-11$ & $4.14 \mathrm{E}-10$ & $-1.85 \mathrm{E}-12$ & $-1.20 \mathrm{E}-12$ & $-6.63 \mathrm{E}-10$ & $-3.36 \mathrm{E}-11$ \\
\hline${ }^{10} \mathrm{~B}$ & $-1.69 \mathrm{E}-04$ & $-1.04 \mathrm{E}-04$ & $0.00 \mathrm{E}+00$ & $0.00 \mathrm{E}+00$ & $-1.20 \mathrm{E}-06$ & $-1.11 \mathrm{E}-06$ & $-7.18 \mathrm{E}-08$ & $-4.92 \mathrm{E}-08$ & $-1.70 \mathrm{E}-04$ & $-1.05 \mathrm{E}-04$ \\
\hline${ }^{11} \mathrm{~B}$ & $-1.44 \mathrm{E}-20$ & $-9.33 \mathrm{E}-21$ & $0.00 \mathrm{E}+00$ & $0.00 \mathrm{E}+00$ & $7.44 \mathrm{E}-18$ & $1.51 \mathrm{E}-17$ & $-2.34 \mathrm{E}-19$ & $-1.52 \mathrm{E}-19$ & $7.20 \mathrm{E}-18$ & $1.50 \mathrm{E}-17$ \\
\hline${ }^{27} \mathrm{Al}$ & $3.76 \mathrm{E}-19$ & $-5.80 \mathrm{E}-20$ & $0.00 \mathrm{E}+00$ & $0.00 \mathrm{E}+00$ & $7.43 \mathrm{E}-18$ & $9.55 \mathrm{E}-18$ & $-1.78 \mathrm{E}-18$ & $-1.21 \mathrm{E}-18$ & $6.03 \mathrm{E}-18$ & $8.29 \mathrm{E}-18$ \\
\hline${ }^{26} \mathrm{Fe}$ & $-1.96 \mathrm{E}-18$ & $-1.12 \mathrm{E}-18$ & $0.00 \mathrm{E}+00$ & $0.00 \mathrm{E}+00$ & $8.28 \mathrm{E}-19$ & $2.87 \mathrm{E}-18$ & $-9.21 \mathrm{E}-19$ & $-7.22 \mathrm{E}-19$ & $-2.01 \mathrm{E}-18$ & $1.05 \mathrm{E}-18$ \\
\hline${ }^{103} \mathrm{Rh}$ & $-2.67 \mathrm{E}-22$ & $-1.95 \mathrm{E}-22$ & $0.00 \mathrm{E}+00$ & $0.00 \mathrm{E}+00$ & $2.41 \mathrm{E}-18$ & $4.61 \mathrm{E}-18$ & $2.37 \mathrm{E}-26$ & $2.04 \mathrm{E}-26$ & $2.41 \mathrm{E}-18$ & $4.61 \mathrm{E}-18$ \\
\hline $\begin{array}{c}\text { PART } \\
>0\end{array}$ & $2.15 \mathrm{E}-12$ & $1.37 \mathrm{E}-12$ & $3.65 \mathrm{E}-16$ & $2.65 \mathrm{E}-16$ & $7.50 \mathrm{E}-11$ & $5.33 \mathrm{E}-10$ & $2.07 \mathrm{E}-17$ & $2.11 \mathrm{E}-17$ & $7.71 \mathrm{E}-11$ & $5.34 \mathrm{E}-10$ \\
\hline $\begin{array}{c}\text { PART } \\
<0\end{array}$ & $-1.69 \mathrm{E}-04$ & $-1.04 \mathrm{E}-04$ & $-2.03 \mathrm{E}-16$ & $-1.28 \mathrm{E}-16$ & $-1.20 \mathrm{E}-06$ & $-1.11 \mathrm{E}-06$ & $-7.18 \mathrm{E}-08$ & $-4.92 \mathrm{E}-08$ & $-1.70 \mathrm{E}-04$ & $-1.05 \mathrm{E}-04$ \\
\hline SUM & $-1.69 \mathrm{E}-04$ & $-1.04 \mathrm{E}-04$ & $1.62 \mathrm{E}-16$ & $1.37 \mathrm{E}-16$ & $-1.20 \mathrm{E}-06$ & $-1.11 \mathrm{E}-06$ & $-7.18 \mathrm{E}-08$ & $-4.92 \mathrm{E}-08$ & $-1.70 \mathrm{E}-04$ & $-1.05 \mathrm{E}-04$ \\
\hline
\end{tabular}

Table 14 : Decomposition of the reactivity effect by isotopes and by reactions due to a ${ }^{10} B$ sample in the central oscillation channel

\begin{tabular}{|c|c|c|c|c|c|c|c|c|c|c|}
\hline \multirow[t]{2}{*}{ ISOTOPE } & \multicolumn{2}{|c|}{ CAPTURE } & \multicolumn{2}{|c|}{ FISSION } & \multicolumn{2}{|c|}{ ELASTIC } & \multicolumn{2}{|c|}{ INELASTIC } & \multicolumn{2}{|c|}{ SUM } \\
\hline & REF & C. Core & REF & C. Core & REF & C. Core & REF & C. Core & REF & C. Core \\
\hline${ }^{235} \mathrm{U}$ & $2.85 \mathrm{E}-17$ & $6.24 \mathrm{E}-18$ & $-7.08 \mathrm{E}-17$ & $-3.39 \mathrm{E}-17$ & $-2.06 \mathrm{E}-18$ & $-9.43 \mathrm{E}-19$ & $-6.75 \mathrm{E}-20$ & $-8.56 \mathrm{E}-19$ & $-4.39 \mathrm{E}-17$ & $-2.91 \mathrm{E}-17$ \\
\hline${ }^{238} \mathrm{U}$ & $2.41 \mathrm{E}-17$ & $8.17 \mathrm{E}-18$ & $-1.15 \mathrm{E}-17$ & $-8.55 \mathrm{E}-18$ & $-2.12 \mathrm{E}-18$ & $-1.20 \mathrm{E}-18$ & $7.55 \mathrm{E}-19$ & $-1.07 \mathrm{E}-19$ & $1.27 \mathrm{E}-17$ & $-7.86 \mathrm{E}-19$ \\
\hline${ }^{238} \mathrm{Pu}$ & $5.27 \mathrm{E}-17$ & $1.18 \mathrm{E}-17$ & $-6.27 \mathrm{E}-17$ & $-6.52 \mathrm{E}-17$ & $-2.88 \mathrm{E}-18$ & $-1.45 \mathrm{E}-18$ & $-1.07 \mathrm{E}-18$ & $-9.91 \mathrm{E}-19$ & $-1.35 \mathrm{E}-17$ & $-5.55 \mathrm{E}-17$ \\
\hline${ }^{239} \mathrm{Pu}$ & $4.02 \mathrm{E}-17$ & $1.10 \mathrm{E}-17$ & $-5.76 \mathrm{E}-17$ & $-3.41 \mathrm{E}-17$ & $-2.23 \mathrm{E}-18$ & $-9.67 \mathrm{E}-19$ & $-7.74 \mathrm{E}-19$ & $-8.03 \mathrm{E}-19$ & $-2.02 \mathrm{E}-17$ & $-2.47 \mathrm{E}-17$ \\
\hline${ }^{240} \mathrm{Pu}$ & 4.91E-17 & $1.50 \mathrm{E}-17$ & $-4.89 \mathrm{E}-17$ & $-3.60 \mathrm{E}-17$ & $-2.81 \mathrm{E}-18$ & $-1.07 \mathrm{E}-18$ & $3.01 \mathrm{E}-19$ & $-3.12 \mathrm{E}-19$ & $-1.86 \mathrm{E}-18$ & $-2.21 \mathrm{E}-17$ \\
\hline${ }^{241} \mathrm{Pu}$ & $1.64 \mathrm{E}-17$ & $7.48 \mathrm{E}-18$ & $-1.37 \mathrm{E}-16$ & $-6.00 \mathrm{E}-17$ & $-2.32 \mathrm{E}-18$ & $-1.16 \mathrm{E}-18$ & $5.60 \mathrm{E}-19$ & $3.57 \mathrm{E}-19$ & $-1.21 \mathrm{E}-16$ & $-5.28 \mathrm{E}-17$ \\
\hline${ }^{242} \mathrm{Pu}$ & $4.00 \mathrm{E}-17$ & $1.67 \mathrm{E}-17$ & $-3.75 \mathrm{E}-17$ & $-3.35 \mathrm{E}-17$ & $-2.64 \mathrm{E}-18$ & $-9.49 \mathrm{E}-19$ & $-4.22 \mathrm{E}-19$ & $-1.21 \mathrm{E}-18$ & $5.16 \mathrm{E}-20$ & $-1.85 \mathrm{E}-17$ \\
\hline${ }^{241} \mathrm{Am}$ & $5.12 \mathrm{E}-17$ & $1.52 \mathrm{E}-17$ & $-5.27 \mathrm{E}-17$ & $-4.38 \mathrm{E}-17$ & $-2.16 \mathrm{E}-18$ & $-1.04 \mathrm{E}-18$ & $2.80 \mathrm{E}-19$ & $-4.94 \mathrm{E}-19$ & $-3.18 \mathrm{E}-18$ & $-3.00 \mathrm{E}-17$ \\
\hline${ }^{16} \mathrm{O}$ & $2.20 \mathrm{E}-12$ & $1.43 \mathrm{E}-12$ & $0.00 \mathrm{E}+00$ & $0.00 \mathrm{E}+00$ & $-8.87 \mathrm{E}-11$ & $-4.62 \mathrm{E}-11$ & $-1.71 \mathrm{E}-12$ & $-1.18 \mathrm{E}-12$ & $-8.89 \mathrm{E}-11$ & $-4.67 \mathrm{E}-11$ \\
\hline $\mathrm{H}$ & $1.18 \mathrm{E}-20$ & $5.01 \mathrm{E}-21$ & $0.00 \mathrm{E}+00$ & $0.00 \mathrm{E}+00$ & $-6.18 \mathrm{E}-17$ & $-3.59 \mathrm{E}-17$ & $0.00 \mathrm{E}+00$ & $0.00 \mathrm{E}+00$ & $-6.18 \mathrm{E}-17$ & $-3.59 \mathrm{E}-17$ \\
\hline${ }^{14} \mathrm{~N}$ & $-3.97 \mathrm{E}-10$ & $-2.29 \mathrm{E}-10$ & $0.00 \mathrm{E}+00$ & $0.00 \mathrm{E}+00$ & $-4.87 \mathrm{E}-10$ & $-1.09 \mathrm{E}-10$ & $-1.66 \mathrm{E}-12$ & $-1.04 \mathrm{E}-12$ & $-8.87 \mathrm{E}-10$ & $-3.40 \mathrm{E}-10$ \\
\hline${ }^{10} \mathrm{~B}$ & $1.04 \mathrm{E}-16$ & $3.78 \mathrm{E}-17$ & $0.00 \mathrm{E}+00$ & $0.00 \mathrm{E}+00$ & $-5.49 \mathrm{E}-18$ & $-3.52 \mathrm{E}-18$ & $2.32 \mathrm{E}-20$ & $2.74 \mathrm{E}-20$ & $9.85 \mathrm{E}-17$ & $3.42 \mathrm{E}-17$ \\
\hline${ }^{11} \mathrm{~B}$ & $-6.83 \mathrm{E}-21$ & $-3.96 \mathrm{E}-21$ & $0.00 \mathrm{E}+00$ & $0.00 \mathrm{E}+00$ & $-9.32 \mathrm{E}-18$ & $-3.04 \mathrm{E}-18$ & $-1.76 \mathrm{E}-19$ & $-1.10 \mathrm{E}-19$ & $-9.49 \mathrm{E}-18$ & $-3.14 \mathrm{E}-18$ \\
\hline${ }^{27} \mathrm{Al}$ & $5.02 \mathrm{E}-19$ & $-2.78 \mathrm{E}-19$ & $0.00 \mathrm{E}+00$ & $0.00 \mathrm{E}+00$ & $-4.16 \mathrm{E}-18$ & $-3.01 \mathrm{E}-18$ & $-1.08 \mathrm{E}-18$ & $-6.71 \mathrm{E}-19$ & $-4.72 \mathrm{E}-18$ & $-3.94 \mathrm{E}-18$ \\
\hline${ }^{26} \mathrm{Fe}$ & $-9.41 \mathrm{E}-19$ & $6.22 \mathrm{E}-19$ & $0.00 \mathrm{E}+00$ & $0.00 \mathrm{E}+00$ & $-4.19 \mathrm{E}-18$ & $-2.52 \mathrm{E}-18$ & $-3.31 \mathrm{E}-19$ & $-2.93 \mathrm{E}-19$ & $-5.44 \mathrm{E}-18$ & $-2.18 \mathrm{E}-18$ \\
\hline${ }^{103} \mathrm{Rh}$ & $-3.05 \mathrm{E}-05$ & $-1.85 \mathrm{E}-05$ & $0.00 \mathrm{E}+00$ & $0.00 \mathrm{E}+00$ & $-3.15 \mathrm{E}-07$ & $-2.98 \mathrm{E}-07$ & $-3.73 \mathrm{E}-06$ & $-2.77 \mathrm{E}-06$ & $-3.45 \mathrm{E}-05$ & $-2.16 \mathrm{E}-05$ \\
\hline $\begin{array}{c}\text { PART } \\
>0\end{array}$ & $2.20 \mathrm{E}-12$ & $1.43 \mathrm{E}-12$ & $0.00 \mathrm{E}+00$ & $0.00 \mathrm{E}+00$ & $0.00 \mathrm{E}+00$ & $0.00 \mathrm{E}+00$ & $1.92 \mathrm{E}-18$ & $3.85 \mathrm{E}-19$ & $6.33 \mathrm{E}-09$ & $3.51 \mathrm{E}-09$ \\
\hline $\begin{array}{c}\text { PART } \\
<0\end{array}$ & $-3.05 \mathrm{E}-05$ & $-1.85 \mathrm{E}-05$ & $-4.79 \mathrm{E}-16$ & $-3.15 \mathrm{E}-16$ & $-3.16 \mathrm{E}-07$ & $-2.98 \mathrm{E}-07$ & $-3.73 \mathrm{E}-06$ & $-2.77 \mathrm{E}-06$ & $-3.45 \mathrm{E}-05$ & $-2.16 \mathrm{E}-05$ \\
\hline SUM & $-3.05 \mathrm{E}-05$ & $-1.85 \mathrm{E}-05$ & $-4.79 \mathrm{E}-16$ & $-3.15 E-16$ & $-3.16 \mathrm{E}-07$ & $-2.98 \mathrm{E}-07$ & $-3.73 E-06$ & $-2.77 \mathrm{E}-06$ & $-3.45 \mathrm{E}-05$ & $-2.16 \mathrm{E}-05$ \\
\hline
\end{tabular}

Table 15 : Decomposition of the reactivity effect by isotopes and by reactions due to a ${ }^{103} \mathrm{Rh}$ sample in the central oscillation channel

- Decomposition of the reactivity effects over 33 energy groups

\begin{tabular}{|c|c|c|c|c|c|c|c|c|c|c|}
\hline GROUP & \multicolumn{2}{|c|}{${ }^{238} \mathrm{Pu}$} & \multicolumn{2}{c|}{${ }^{239} \mathrm{Pu}$} & \multicolumn{2}{c|}{${ }^{235} \mathrm{U}$} & \multicolumn{2}{c|}{${ }^{103} \mathrm{Rh}$} \\
\hline & REF & C. Core & REF & C. Core & REF & C. Core & REF & C. Core & REF & C. Core \\
\hline 1 & $2.44 \mathrm{E}-07$ & $1.56 \mathrm{E}-07$ & $2.00 \mathrm{E}-07$ & $1.38 \mathrm{E}-07$ & $1.27 \mathrm{E}-07$ & $8.06 \mathrm{E}-08$ & $-9.46 \mathrm{E}-09$ & $-6.31 \mathrm{E}-09$ & $-5.59 \mathrm{E}-09$ & $-4.57 \mathrm{E}-09$ \\
\hline
\end{tabular}




\begin{tabular}{|c|c|c|c|c|c|c|c|c|c|c|}
\hline 2 & 3.34E-06 & 2.17E-06 & $2.53 \mathrm{E}-06$ & $1.82 \mathrm{E}-06$ & $1.51 \mathrm{E}-06$ & 9.72E-07 & $-1.88 \mathrm{E}-07$ & $-1.26 \mathrm{E}-07$ & $-2.23 \mathrm{E}-07$ & $-1.56 \mathrm{E}-07$ \\
\hline 3 & $1.05 \mathrm{E}-05$ & 6.77E-06 & $8.48 \mathrm{E}-06$ & $6.07 \mathrm{E}-06$ & $3.77 \mathrm{E}-06$ & $2.41 \mathrm{E}-06$ & $-7.86 \mathrm{E}-07$ & $-5.14 \mathrm{E}-07$ & $-4.57 \mathrm{E}-07$ & $-3.17 \mathrm{E}-07$ \\
\hline 4 & 2.23E-05 & $1.44 \mathrm{E}-05$ & $1.84 \mathrm{E}-05$ & $1.29 \mathrm{E}-05$ & $7.85 \mathrm{E}-06$ & 5.01E-06 & $-1.90 \mathrm{E}-06$ & $-1.24 \mathrm{E}-06$ & $-1.33 \mathrm{E}-06$ & $-9.05 \mathrm{E}-07$ \\
\hline 5 & 2.71E-05 & $1.73 \mathrm{E}-05$ & 2.34E-05 & $1.59 \mathrm{E}-05$ & $1.06 \mathrm{E}-05$ & $6.70 \mathrm{E}-06$ & $-2.64 \mathrm{E}-06$ & $-1.70 \mathrm{E}-06$ & $-1.45 \mathrm{E}-06$ & $-9.69 \mathrm{E}-07$ \\
\hline 6 & $2.84 \mathrm{E}-05$ & $1.82 \mathrm{E}-05$ & 2.38E-05 & $1.59 \mathrm{E}-05$ & $1.14 \mathrm{E}-05$ & 7.25E-06 & $-1.39 \mathrm{E}-06$ & $-8.78 \mathrm{E}-07$ & $-7.72 \mathrm{E}-07$ & $-5.27 \mathrm{E}-07$ \\
\hline 7 & $3.83 \mathrm{E}-05$ & $2.50 \mathrm{E}-05$ & $3.62 \mathrm{E}-05$ & $2.40 \mathrm{E}-05$ & $1.80 \mathrm{E}-05$ & $1.16 \mathrm{E}-05$ & $-4.65 \mathrm{E}-06$ & $-3.03 \mathrm{E}-06$ & $-1.30 \mathrm{E}-06$ & $-9.90 \mathrm{E}-07$ \\
\hline 8 & $2.14 \mathrm{E}-05$ & $1.39 \mathrm{E}-05$ & $2.95 \mathrm{E}-05$ & $1.93 \mathrm{E}-05$ & $1.65 \mathrm{E}-05$ & $1.06 \mathrm{E}-05$ & $-7.39 \mathrm{E}-06$ & $-4.74 \mathrm{E}-06$ & $-1.83 \mathrm{E}-06$ & $-1.27 \mathrm{E}-06$ \\
\hline 9 & $1.75 \mathrm{E}-05$ & $1.13 \mathrm{E}-05$ & $3.27 \mathrm{E}-05$ & $2.12 \mathrm{E}-05$ & $2.05 \mathrm{E}-05$ & $1.32 \mathrm{E}-05$ & $-1.22 \mathrm{E}-05$ & $-7.68 \mathrm{E}-06$ & $-2.99 \mathrm{E}-06$ & $-1.91 \mathrm{E}-06$ \\
\hline 10 & $1.22 \mathrm{E}-05$ & $7.86 \mathrm{E}-06$ & $3.23 \mathrm{E}-05$ & $2.08 \mathrm{E}-05$ & 2.22E-05 & $1.44 \mathrm{E}-05$ & $-1.60 \mathrm{E}-05$ & $-9.81 \mathrm{E}-06$ & $-3.88 \mathrm{E}-06$ & $-2.40 \mathrm{E}-06$ \\
\hline 11 & $9.19 \mathrm{E}-06$ & $5.99 \mathrm{E}-06$ & 2.69E-05 & $1.72 \mathrm{E}-05$ & $1.97 \mathrm{E}-05$ & $1.29 \mathrm{E}-05$ & $-1.58 \mathrm{E}-05$ & $-9.42 \mathrm{E}-06$ & $-4.05 E-06$ & $-2.43 E-06$ \\
\hline 12 & 7.70E-06 & 5.14E-06 & 2.04E-05 & $1.31 \mathrm{E}-05$ & $1.69 \mathrm{E}-05$ & $1.13 \mathrm{E}-05$ & $-1.45 \mathrm{E}-05$ & $-8.56 \mathrm{E}-06$ & $-3.89 \mathrm{E}-06$ & $-2.31 \mathrm{E}-06$ \\
\hline 13 & $6.45 \mathrm{E}-06$ & 4.38E-06 & $1.58 \mathrm{E}-05$ & $1.03 \mathrm{E}-05$ & $1.52 \mathrm{E}-05$ & $1.02 \mathrm{E}-05$ & $-1.45 \mathrm{E}-05$ & $-8.49 \mathrm{E}-06$ & $-3.26 \mathrm{E}-06$ & $-1.92 \mathrm{E}-06$ \\
\hline 14 & 5.03E-06 & $3.47 \mathrm{E}-06$ & $1.22 \mathrm{E}-05$ & 8.02E-06 & $1.33 \mathrm{E}-05$ & $9.03 \mathrm{E}-06$ & $-1.45 \mathrm{E}-05$ & $-8.43 \mathrm{E}-06$ & $-2.92 \mathrm{E}-06$ & $-1.70 \mathrm{E}-06$ \\
\hline 15 & $3.42 \mathrm{E}-06$ & $2.40 \mathrm{E}-06$ & 8.32E-06 & $5.56 \mathrm{E}-06$ & $1.06 \mathrm{E}-05$ & $7.26 \mathrm{E}-06$ & $-1.33 \mathrm{E}-05$ & $-7.77 \mathrm{E}-06$ & $-2.26 \mathrm{E}-06$ & $-1.32 \mathrm{E}-06$ \\
\hline 16 & $1.94 \mathrm{E}-06$ & $1.38 \mathrm{E}-06$ & 4.89E-06 & $3.32 \mathrm{E}-06$ & $6.49 \mathrm{E}-06$ & $4.50 \mathrm{E}-06$ & $-1.04 \mathrm{E}-05$ & $-6.25 \mathrm{E}-06$ & $-1.44 \mathrm{E}-06$ & $-8.59 \mathrm{E}-07$ \\
\hline 17 & $9.78 \mathrm{E}-07$ & 7.03E-07 & $2.46 \mathrm{E}-06$ & $1.69 \mathrm{E}-06$ & 4.30E-06 & $2.98 \mathrm{E}-06$ & $-7.03 \mathrm{E}-06$ & $-4.32 \mathrm{E}-06$ & $-7.60 \mathrm{E}-07$ & $-4.63 \mathrm{E}-07$ \\
\hline 18 & 2.89E-07 & $2.11 \mathrm{E}-07$ & $1.11 \mathrm{E}-06$ & $7.51 \mathrm{E}-07$ & $1.55 \mathrm{E}-06$ & $1.09 \mathrm{E}-06$ & $-3.03 \mathrm{E}-06$ & $-1.88 \mathrm{E}-06$ & $-2.67 \mathrm{E}-07$ & $-1.64 \mathrm{E}-07$ \\
\hline 19 & 8.84E-07 & $6.71 \mathrm{E}-07$ & $3.17 \mathrm{E}-06$ & 2.23E-06 & 4.72E-06 & $3.50 \mathrm{E}-06$ & $-1.15 \mathrm{E}-05$ & $-7.26 \mathrm{E}-06$ & $-6.92 \mathrm{E}-07$ & $-4.38 \mathrm{E}-07$ \\
\hline 20 & 5.38E-07 & 4.19E-07 & $3.19 \mathrm{E}-06$ & $2.21 \mathrm{E}-06$ & $3.10 \mathrm{E}-06$ & 2.37E-06 & $-9.20 \mathrm{E}-06$ & $-5.99 \mathrm{E}-06$ & $-3.44 \mathrm{E}-07$ & $-2.23 \mathrm{E}-07$ \\
\hline 21 & $1.34 \mathrm{E}-07$ & $1.20 \mathrm{E}-07$ & $1.33 \mathrm{E}-06$ & $9.61 \mathrm{E}-07$ & 2.01E-06 & $1.57 \mathrm{E}-06$ & $-5.45 \mathrm{E}-06$ & $-3.73 \mathrm{E}-06$ & $-2.33 \mathrm{E}-07$ & $-1.58 \mathrm{E}-07$ \\
\hline 22 & $-4.09 \mathrm{E}-08$ & $-2.56 \mathrm{E}-08$ & 4.25E-07 & $3.20 \mathrm{E}-07$ & $5.32 \mathrm{E}-07$ & 4.44E-07 & $-2.03 \mathrm{E}-06$ & $-1.50 \mathrm{E}-06$ & $-8.62 \mathrm{E}-08$ & $-6.29 \mathrm{E}-08$ \\
\hline 23 & 2.89E-08 & $3.23 \mathrm{E}-08$ & $3.48 \mathrm{E}-07$ & $3.09 \mathrm{E}-07$ & $3.02 \mathrm{E}-07$ & $3.07 \mathrm{E}-07$ & $-1.42 \mathrm{E}-06$ & $-1.32 \mathrm{E}-06$ & $-6.21 \mathrm{E}-08$ & $-5.68 \mathrm{E}-08$ \\
\hline 24 & $-9.74 \mathrm{E}-09$ & $-1.27 \mathrm{E}-08$ & $5.20 \mathrm{E}-08$ & $6.30 \mathrm{E}-08$ & $2.57 \mathrm{E}-08$ & $3.81 \mathrm{E}-08$ & $-1.99 \mathrm{E}-07$ & $-2.69 \mathrm{E}-07$ & $-4.61 E-09$ & $-5.92 \mathrm{E}-09$ \\
\hline 25 & $-1.57 \mathrm{E}-09$ & $-2.92 \mathrm{E}-09$ & $1.02 \mathrm{E}-08$ & $1.54 \mathrm{E}-08$ & 2.66E-09 & 5.41E-09 & $-3.29 \mathrm{E}-08$ & $-6.42 \mathrm{E}-08$ & $-2.05 \mathrm{E}-10$ & $-4.15 \mathrm{E}-10$ \\
\hline 26 & $-8.94 \mathrm{E}-11$ & $-3.32 \mathrm{E}-10$ & 2.93E-09 & 8.34E-09 & $1.34 \mathrm{E}-09$ & $5.23 \mathrm{E}-09$ & $-9.96 \mathrm{E}-09$ & $-3.92 \mathrm{E}-08$ & $-8.56 \mathrm{E}-11$ & $-3.57 \mathrm{E}-10$ \\
\hline 27 & $3.33 \mathrm{E}-12$ & $4.86 \mathrm{E}-11$ & $1.31 \mathrm{E}-10$ & $1.80 \mathrm{E}-09$ & $6.54 \mathrm{E}-10$ & 9.82E-09 & $-9.76 \mathrm{E}-10$ & $-1.53 \mathrm{E}-08$ & $-1.37 \mathrm{E}-12$ & $-9.84 \mathrm{E}-12$ \\
\hline 28 & $-5.81 \mathrm{E}-12$ & $-1.25 \mathrm{E}-10$ & $3.49 \mathrm{E}-11$ & $6.73 \mathrm{E}-10$ & $4.68 \mathrm{E}-11$ & $1.01 \mathrm{E}-09$ & $-1.70 \mathrm{E}-10$ & $-4.21 \mathrm{E}-09$ & $2.80 \mathrm{E}-13$ & $9.26 \mathrm{E}-12$ \\
\hline 29 & $-1.62 \mathrm{E}-12$ & $-1.62 \mathrm{E}-10$ & 4.37E-12 & $3.73 \mathrm{E}-10$ & $-1.90 \mathrm{E}-12$ & $-1.53 \mathrm{E}-10$ & $-7.53 \mathrm{E}-11$ & $-9.16 \mathrm{E}-09$ & $-4.13 E-13$ & $-4.94 \mathrm{E}-11$ \\
\hline 30 & $-3.01 \mathrm{E}-13$ & $-1.48 \mathrm{E}-11$ & $1.64 \mathrm{E}-11$ & $6.67 \mathrm{E}-10$ & $1.96 \mathrm{E}-12$ & $9.66 \mathrm{E}-11$ & $-6.69 \mathrm{E}-11$ & $-3.50 \mathrm{E}-09$ & $-9.06 \mathrm{E}-13$ & $-4.78 \mathrm{E}-11$ \\
\hline 31 & $-5.85 \mathrm{E}-12$ & $-4.65 \mathrm{E}-10$ & $8.27 \mathrm{E}-11$ & $6.00 \mathrm{E}-09$ & $3.09 \mathrm{E}-11$ & $2.57 \mathrm{E}-09$ & $-1.84 \mathrm{E}-10$ & $-1.53 \mathrm{E}-08$ & $-4.66 \mathrm{E}-11$ & $-3.82 \mathrm{E}-09$ \\
\hline 32 & $-6.77 \mathrm{E}-11$ & $-4.58 \mathrm{E}-11$ & $1.78 \mathrm{E}-11$ & $-1.94 \mathrm{E}-13$ & $1.87 \mathrm{E}-11$ & $9.08 \mathrm{E}-12$ & $-1.32 \mathrm{E}-10$ & $5.63 \mathrm{E}-11$ & $-8.46 \mathrm{E}-11$ & $-6.68 \mathrm{E}-11$ \\
\hline 33 & $-1.37 \mathrm{E}-10$ & $7.95 \mathrm{E}-10$ & $2.78 \mathrm{E}-11$ & $-1.46 \mathrm{E}-10$ & $1.77 \mathrm{E}-11$ & $-1.45 \mathrm{E}-10$ & $-1.76 \mathrm{E}-10$ & $3.18 \mathrm{E}-09$ & $-1.04 \mathrm{E}-10$ & $2.76 \mathrm{E}-10$ \\
\hline $\begin{array}{c}\text { PART } \\
>0\end{array}$ & $2.47 \mathrm{E}-04$ & $1.60 \mathrm{E}-04$ & $3.37 \mathrm{E}-04$ & 2.22E-04 & $2.50 \mathrm{E}-04$ & $1.65 \mathrm{E}-04$ & $3.54 \mathrm{E}-07$ & 2.33E-07 & $1.15 \mathrm{E}-07$ & 7.66E-08 \\
\hline $\begin{array}{c}\text { PART } \\
<0\end{array}$ & $-2.94 \mathrm{E}-05$ & $-1.83 \mathrm{E}-05$ & $-2.88 \mathrm{E}-05$ & $-1.79 \mathrm{E}-05$ & $-3.91 \mathrm{E}-05$ & $-2.48 \mathrm{E}-05$ & $-1.70 \mathrm{E}-04$ & $-1.05 \mathrm{E}-04$ & $-3.46 \mathrm{E}-05$ & $-2.16 \mathrm{E}-05$ \\
\hline SUM & $2.18 \mathrm{E}-04$ & $1.42 \mathrm{E}-04$ & $3.08 \mathrm{E}-04$ & $2.04 \mathrm{E}-04$ & $2.11 \mathrm{E}-04$ & $1.40 \mathrm{E}-04$ & $-1.70 \mathrm{E}-04$ & $-1.05 \mathrm{E}-04$ & $-3.45 \mathrm{E}-05$ & $-2.16 \mathrm{E}-05$ \\
\hline
\end{tabular}

Table 16 : Decomposition of the reactivity effects by energy groups due to central samples

The following figures illustrate the energy profile of the reactivity effects in both coupled core and fast reference configurations. A normalization coefficient is applied to the coupled core values in order to get the same total reactivity effect as in the fast reference configuration: 


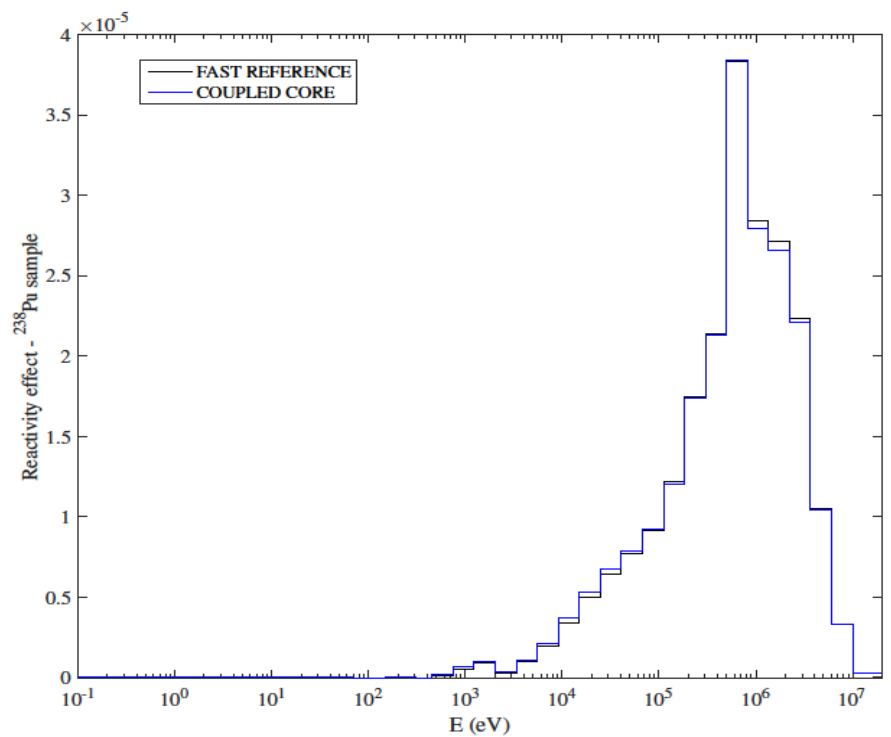

Figure 13 : Energy profiles of reactivity effect $-{ }^{238} \mathrm{Pu}$ sample

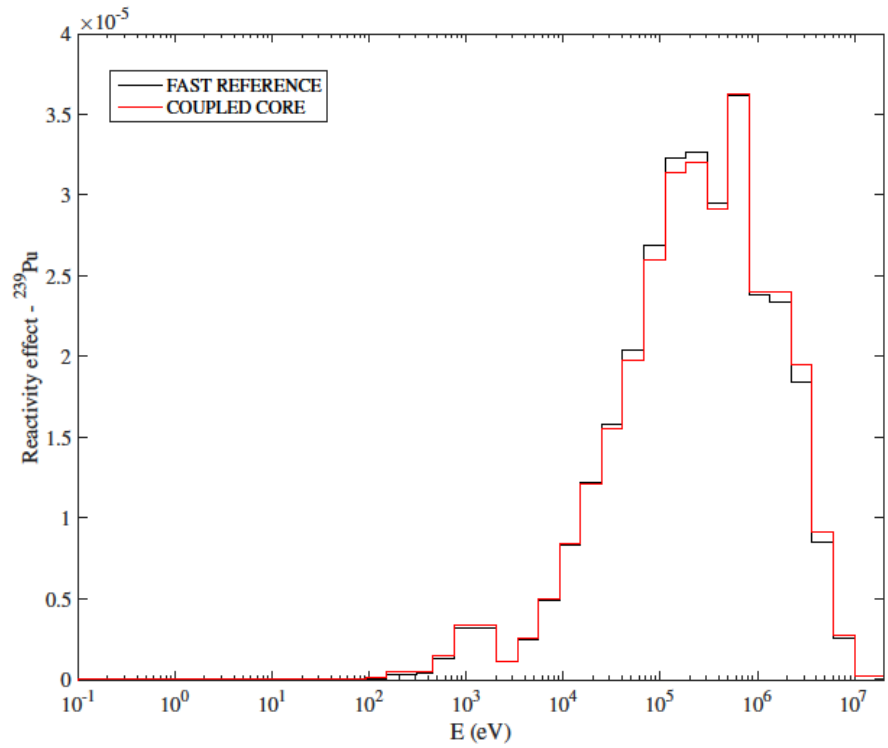

Figure 14 : Energy profiles of reactivity effect $-{ }^{239} \mathrm{Pu}$ sample 


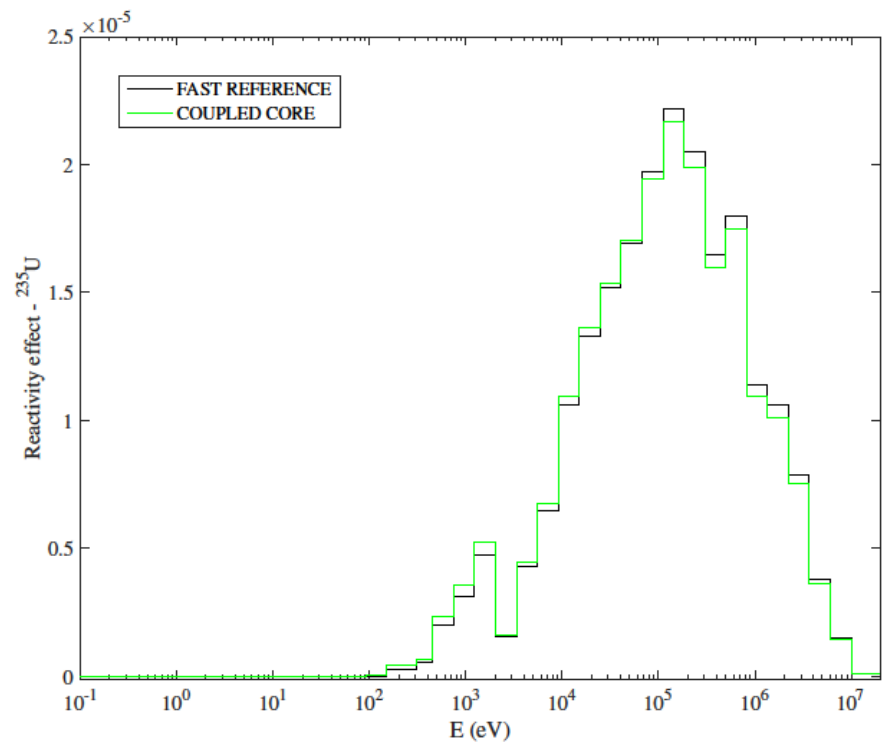

Figure 15 : Energy profiles of reactivity effect - ${ }^{235} \mathrm{U}$ sample

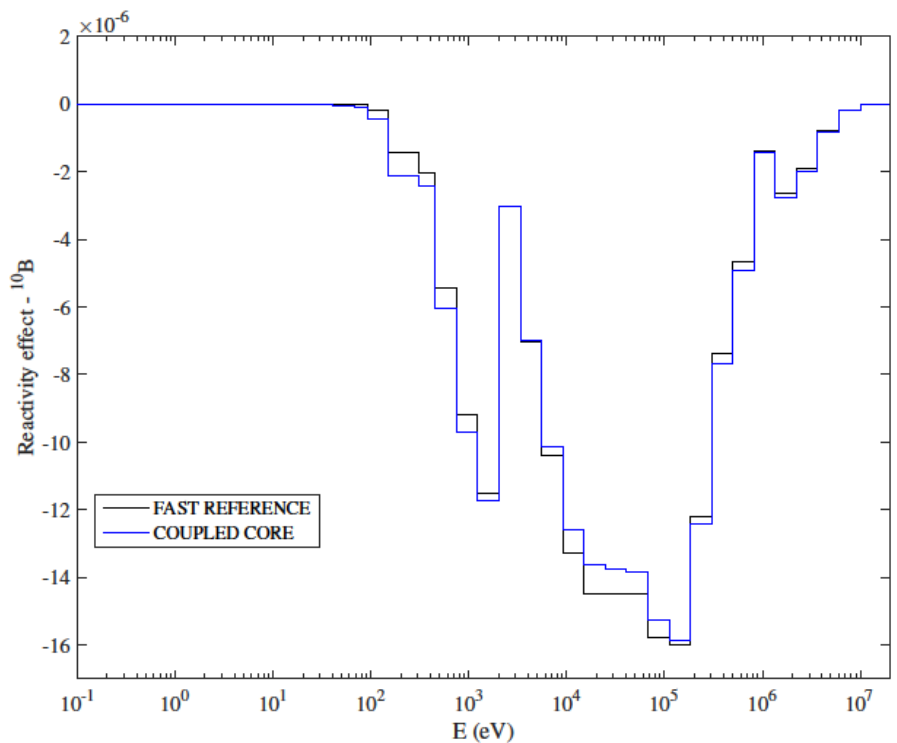

Figure 16 : Energy profiles of reactivity effect $-{ }^{10} \mathrm{~B}$ sample 


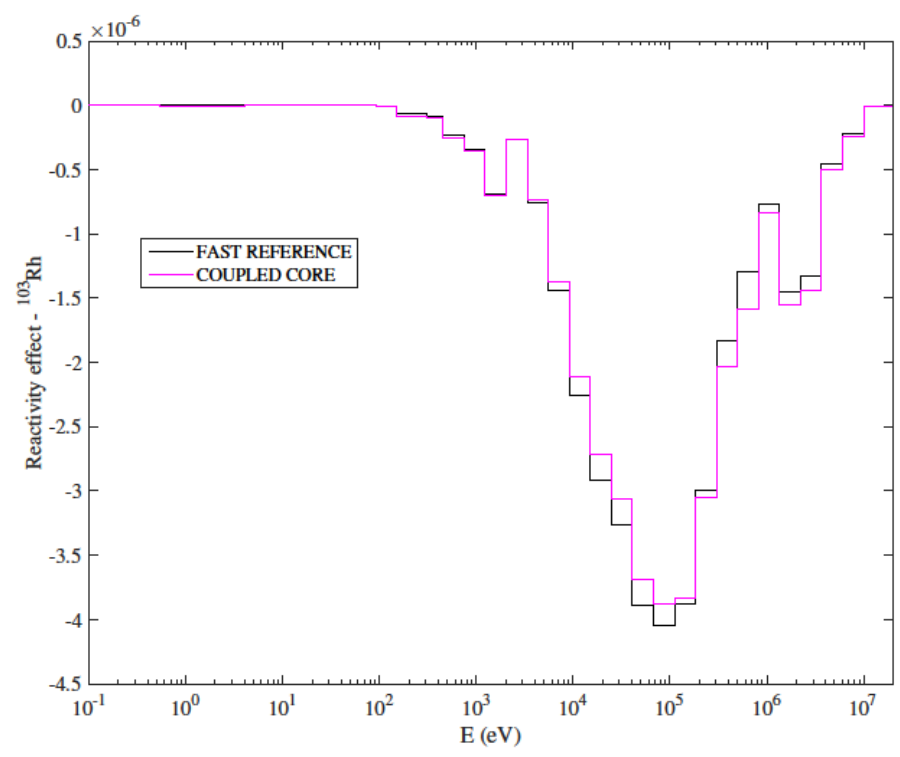

Figure 17 : Energy profiles of reactivity effect $-{ }^{103} \mathrm{Rh}$ sample

It appears that for the five isotopes covering the whole energy domains, the decompositions of the reactivity effects over the isotopes, the main reactions and the 33 energy groups remain very close. Some discrepancies can be observed, especially in the low energy groups (from 28 to 33 i.e. under $15 \mathrm{eV}$ ). However, such differences are negligible in comparison to the main reactivity effect. Then, reactivity measurements in fast-thermal coupled cores would be spectraly equivalent to one performed in an entirely fast configuration.

\section{EXPERIMENTAL AND OPERATIONAL CHARACTERISTICS}

This section details two important elements for a safe operation and pertinent measurements in the oscillation technique. The first section presents a pre-dimensioning of oscillation samples thanks to reactivity per gram extrapolated from several small fictive samples. Then, in the following section, the behavior of the coupled configurations is studied in case of accidental flooding.

\subsection{Reactivity effect per gram: pre-dimensioning of oscillation samples}

In the oscillation technique used in MINERVE, reactivity effects can be measured with a precision around $0.01 \mathrm{pcm}\left(10^{-7} \Delta \mathrm{k} / \mathrm{k}\right)$. Generally, samples are designed in order to represent between 1 and $10 \mathrm{pcm}$. Then, the uncertainty on the measured effect lies between 0.1 and 1 $\%$. Depending of several characteristics such as scattering or absorption cross-sections, two different quantities of two different isotopes must be put into a sample in order to get the 
same reactivity effect. That explains why, during the ERMINE V campaign, 20g were sometimes necessary to get a sufficient reactivity effect (Martin-Deidier, 1979).

The effect of the insertion of a very small quantity of several isotopes of interest is evaluated using the same 'EXACT_SPT' module from the ERANOS code which calculates reactivity effects thanks to the exact formulation of the standard perturbation theory $\Delta \rho=\frac{\left\langle\Phi_{R E F}^{+} ;\left(-\Delta L+\Delta T+\frac{\Delta F}{k_{R E F}}\right) \Phi_{P E R T}\right\rangle}{\left\langle\Phi_{R E F}^{+} ; F_{P E R T} \Phi_{P E R T}\right\rangle}$. It allows calculating a reactivity effect per gram without self-shielding.

The Table 18 here below presents extrapolated reactivity effects per gram (in $10^{-5} \Delta \mathrm{k} / \mathrm{k}$ per g) for several isotopes of interest within the frame of GEN IV sodium fast reactors:

\begin{tabular}{|c|c|c|c|}
\hline ISOTOPES & \multicolumn{3}{|c|}{ CONFIGURATION } \\
\hline & Fast reference & Optimized without $B_{4} C$ & Optimized with $B_{4} C$ \\
\hline${ }^{235} \mathrm{U}$ & $1,71 \mathrm{E}-01$ & $1,45 \mathrm{E}-01$ & $1,13 \mathrm{E}-01$ \\
\hline${ }^{238} \mathrm{U}$ & $-9,64 \mathrm{E}-03$ & $-7,02 \mathrm{E}-03$ & $-5,33 \mathrm{E}-03$ \\
\hline${ }^{238} \mathrm{Pu}$ & $1,63 \mathrm{E}-01$ & $1,37 \mathrm{E}-01$ & $1,06 \mathrm{E}-01$ \\
\hline${ }^{239} \mathrm{Pu}$ & $2,38 \mathrm{E}-01$ & $2,00 \mathrm{E}-01$ & $1,55 \mathrm{E}-01$ \\
\hline${ }^{240} \mathrm{Pu}$ & $4,98 \mathrm{E}-02$ & $4,26 \mathrm{E}-02$ & $3,31 \mathrm{E}-02$ \\
\hline${ }^{241} \mathrm{Pu}$ & $3,22 \mathrm{E}-01$ & $2,72 \mathrm{E}-01$ & $2,11 \mathrm{E}-01$ \\
\hline${ }^{242} \mathrm{Pu}$ & $3,25 \mathrm{E}-02$ & $2,82 \mathrm{E}-02$ & $2,20 \mathrm{E}-02$ \\
\hline${ }^{10} \mathrm{~B}$ & $-3,59 \mathrm{E}+00$ & $-3,06 \mathrm{E}+00$ & $-2,25 \mathrm{E}+00$ \\
\hline${ }^{\mathrm{C}-\mathrm{nat}}$ & $-1,64 \mathrm{E}-02$ & $-1,81 \mathrm{E}-02$ & $-1,68 \mathrm{E}-02$ \\
\hline${ }^{1} \mathrm{H}$ & $3,15 \mathrm{E}+00$ & $1,86 \mathrm{E}+00$ & $1,15 \mathrm{E}+00$ \\
\hline${ }^{56} \mathrm{Fe}$ & $-5,71 \mathrm{E}-03$ & $-3,98 \mathrm{E}-03$ & $-3,13 \mathrm{E}-03$ \\
\hline${ }^{103} \mathrm{Rh}$ & $-6,46 \mathrm{E}-02$ & $-5,25 \mathrm{E}-02$ & $-3,95 \mathrm{E}-02$ \\
\hline${ }^{99} \mathrm{Tc}$ & $-7,28 \mathrm{E}-02$ & $-5,93 \mathrm{E}-02$ & $-4,48 \mathrm{E}-02$ \\
\hline${ }^{133} \mathrm{Cs}$ & $-3,13 \mathrm{E}-02$ & $-2,53 \mathrm{E}-02$ & $-1,91 \mathrm{E}-02$ \\
\hline
\end{tabular}

Table 17: Comparison of reactivity effects per gram for isotopes of interest

Then, even with $10 \%$ of fissions occurring in the ZONA1 test zone, the same order of magnitude for sample reactivity worth is obtained than in the fast reference configuration.

The Table 19 below details the needed masses of these isotopes (in g) in order to get a reactivity measurement of $1 \mathrm{pcm}$ to get $1 \%$ of uncertainty (oscillation measurements in MINERVE ZPR are entached to a $10^{-7} \Delta \mathrm{k} / \mathrm{k}$ uncertainty assuming 5 measurements of 10 repeated cycles at a reactor power of $50 \mathrm{~W}$ ).

\begin{tabular}{|c|c|c|c|}
\hline ISOTOPES & \multicolumn{3}{|c|}{ CONFIGURATION } \\
\hline & Fast reference & Optimized without $\mathrm{B}_{4} \mathrm{C}$ & Optimized with $\mathrm{B}_{4} \mathrm{C}$ \\
\hline${ }^{235} \mathrm{U}$ & 5,8 & 6,9 & 8,8 \\
\hline${ }^{238} \mathrm{U}$ & 103,7 & 142,5 & 187,6 \\
\hline
\end{tabular}




\begin{tabular}{|c|c|c|c|}
${ }^{238} \mathrm{Pu}$ & 6,1 & 7,3 & 9,4 \\
\hline${ }^{239} \mathrm{Pu}$ & 4,2 & 5,0 & 6,5 \\
\hline${ }^{240} \mathrm{Pu}$ & 20,1 & 23,5 & 30,2 \\
\hline${ }^{241} \mathrm{Pu}$ & 3,1 & 3,7 & 4,7 \\
\hline${ }^{242} \mathrm{Pu}$ & 30,8 & 35,5 & 45,5 \\
\hline${ }^{10} \mathrm{~B}$ & 0,3 & 0,3 & 0,4 \\
\hline $\mathrm{C}-\mathrm{nat}$ & 61,0 & 55,2 & 59,5 \\
\hline${ }^{1} \mathrm{H}$ & 0,3 & 0,5 & 0,9 \\
\hline${ }^{56} \mathrm{Fe}$ & 175,1 & 251,3 & 319,5 \\
\hline${ }^{103} \mathrm{Rh}$ & 15,5 & 19,0 & 25,3 \\
\hline${ }^{99} \mathrm{Tc}$ & 13,7 & 16,9 & 22,3 \\
\hline${ }^{133} \mathrm{Cs}$ & 31,9 & 39,5 & 52,4 \\
\hline \multicolumn{3}{|c|}{ Tableau 18 : Needed masses to get a 1pcm reactivity effect (in g) }
\end{tabular}

Then, the fast reference leads to higher reactivity effects. However, the same orders of magnitude are obtained for both coupled configurations. This may be the only conclusion to draw. Indeed, even if the spectra are very close, the thermal component in the optimized configuration without $\mathrm{B}_{4} \mathrm{C}$ could increase the reactivity effect but not in the targeted energy region.

\subsection{Flooding studies}

The feasibility of an experimental configuration deeply depends on its safety characteristics. In ZPRs, accidental injections of reactivity above $\beta_{\text {eff }}$ is the main safety concern. It includes various situations such as fuel and reflector loading errors or accidental drop of a fissile sample. As far as fast-thermal coupled cores are concerned, accidental flooding of the fast air zone stands for the main risk of prompt criticality, or at least fast transients (Pesic, 1991). Flooding can come from a leakage between the thermal zone to the fast air zone or an addition of water in the exceptional case of fire in the facility. Obviously, mechanical solutions such as suspending the core can be set up; however, neutronics stability during a flooding of the fast zone remains the best safety option.

In this section, first calculations are presented to get a better understanding of the phenomena involved during a flooding of the fast zone. On the one hand, variations of reactivity are presented for both the fast reference and the optimized configurations. On the other hand, the evolution of reactivity during the flooding of the optimized configuration with $\mathrm{B}_{4} \mathrm{C}$ gives several explanations of the physical background of flooded situations in fast-thermal coupled cores.

\subsubsection{Order of magnitudes of the reactivity variations in case of flooding}


When a fast zone is flooded, the spectrum is rapidly softened due to the moderation on hydrogen atoms. Therefore, as the fuel in a fast zone is enriched, the reactivity strongly increases. This phenomenon is observed when the fast reference configuration is flooded (Figure 9):

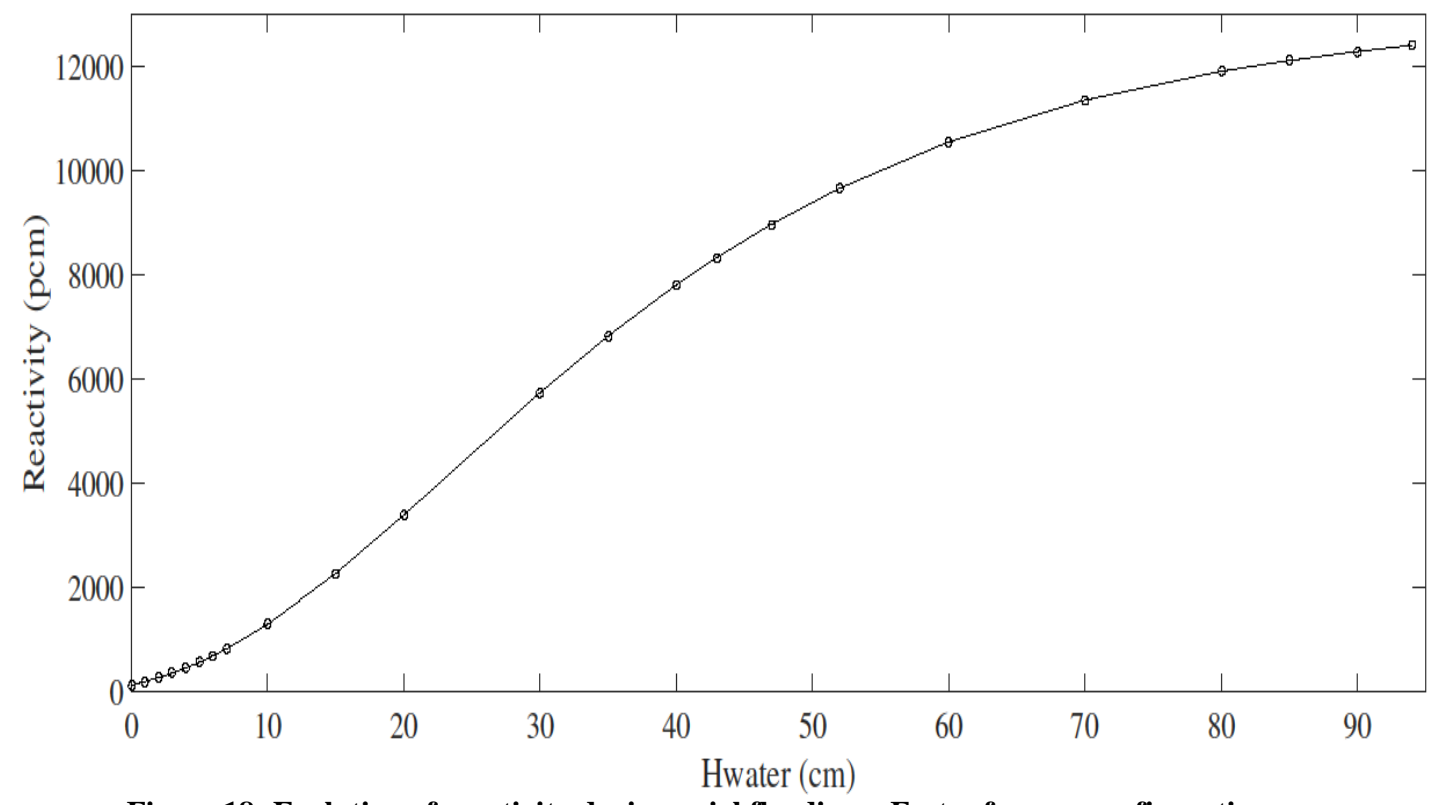

Figure 18: Evolution of reactivity during axial flooding - Fast reference configuration

The total flooding reactivity is always positive and reaches $12410 \mathrm{pcm}$.

When a flooding of the fast zone is simulated in the optimized fast-thermal coupled core, the size of the fast zone is reduced and its composition differs from the fast reference configuration. Consequently, the increase of reactivity is reduced compared to the reference fast case. 


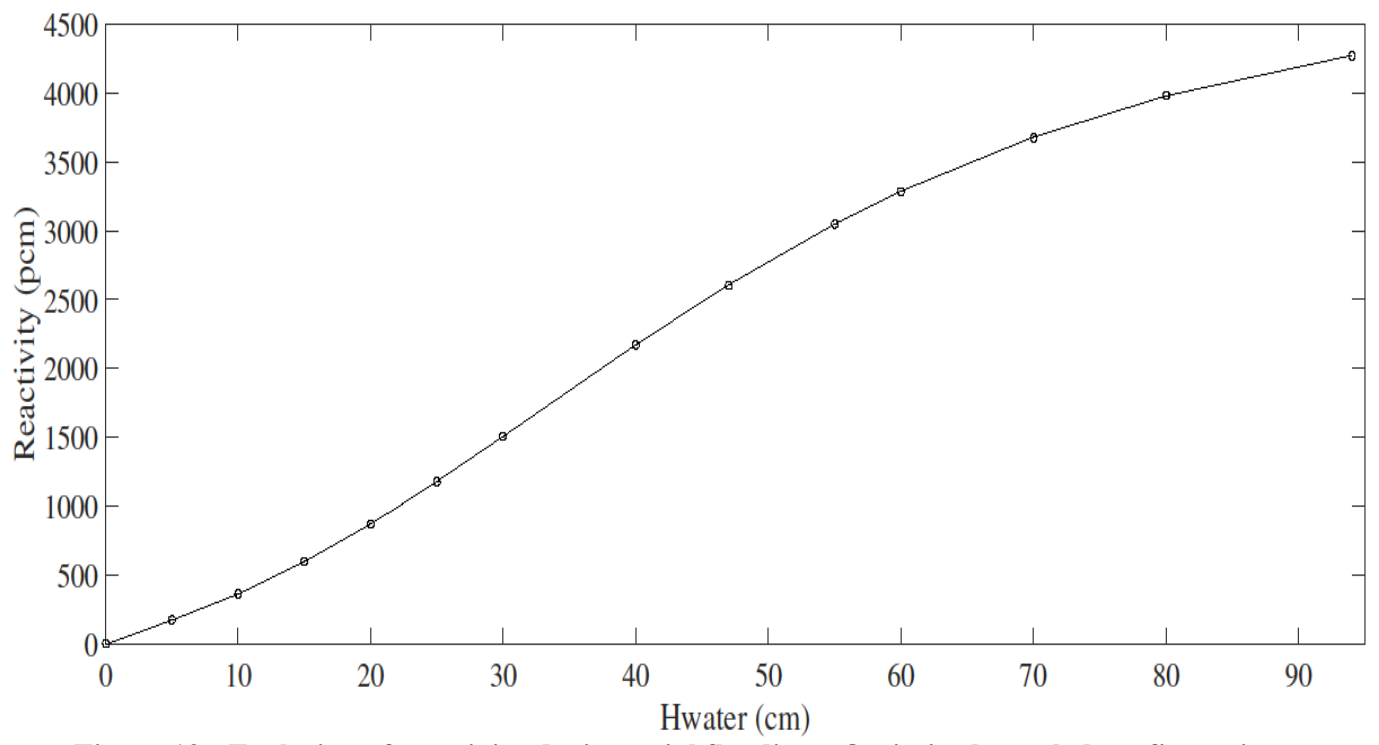

Figure 19 : Evolution of reactivity during axial flooding - Optimized coupled configuration

In this configuration, the total flooding reactivity is still always positive but reduced to $4270 \mathrm{pcm}$.

Moreover, the addition of a $\mathrm{B}_{4} \mathrm{C}$ ring close to the ZONA1 cells significantly reduces the flooding reactivity, as shown below on Figure 11.

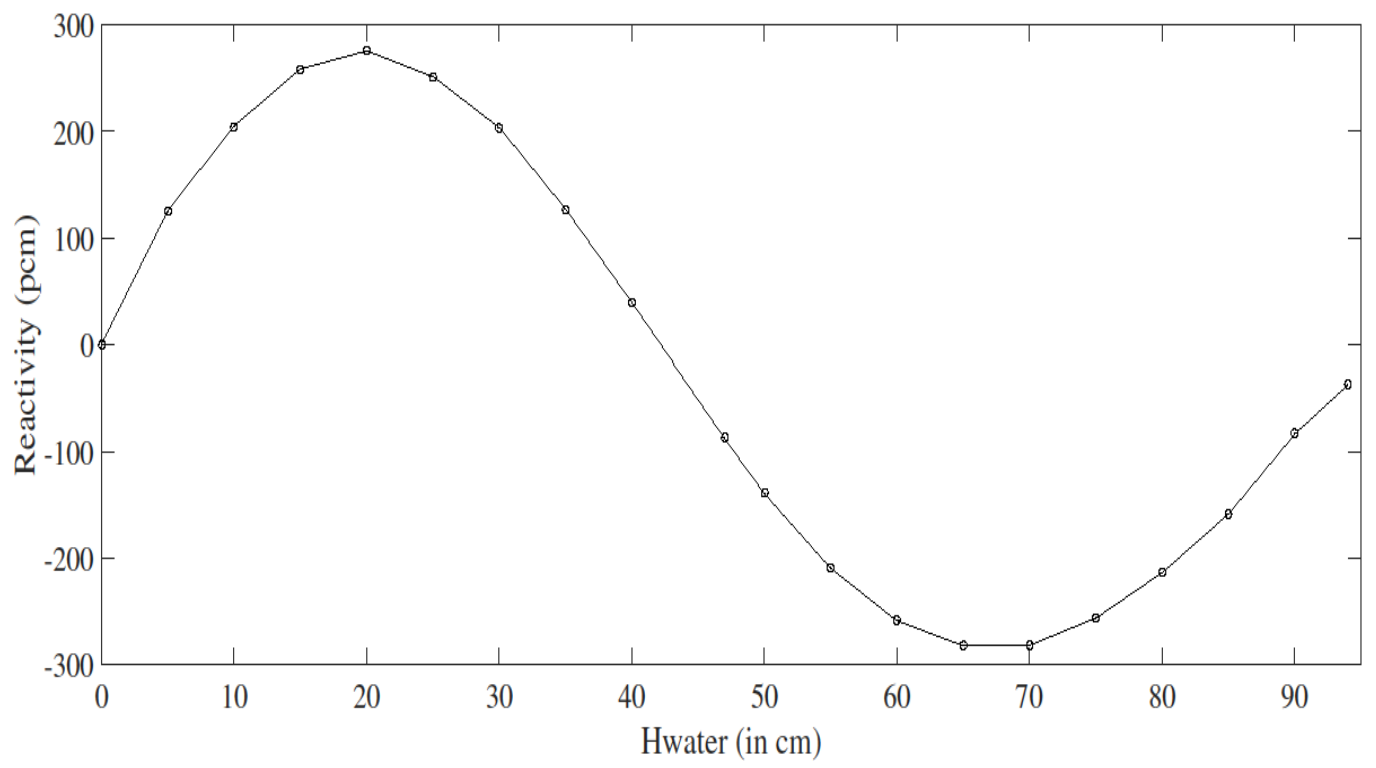

Figure 20: Evolution of reactivity during axial flooding - Optimized configuration with $\mathrm{B}_{4} \mathrm{C}$

A total reactivity variation close to zero is obtained $(-37 \mathrm{pcm})$. The sinusoidal shape curve obtained is due to the adaptation zone and results from a balance between opposite effects. The next section aims to give a better understanding of these phenomena.

\subsubsection{Elements to understand the physical balance involved in the flooding}


As it can be observed on Figure 12, the total flooding reactivity results from opposite and high amplitudes tendencies.

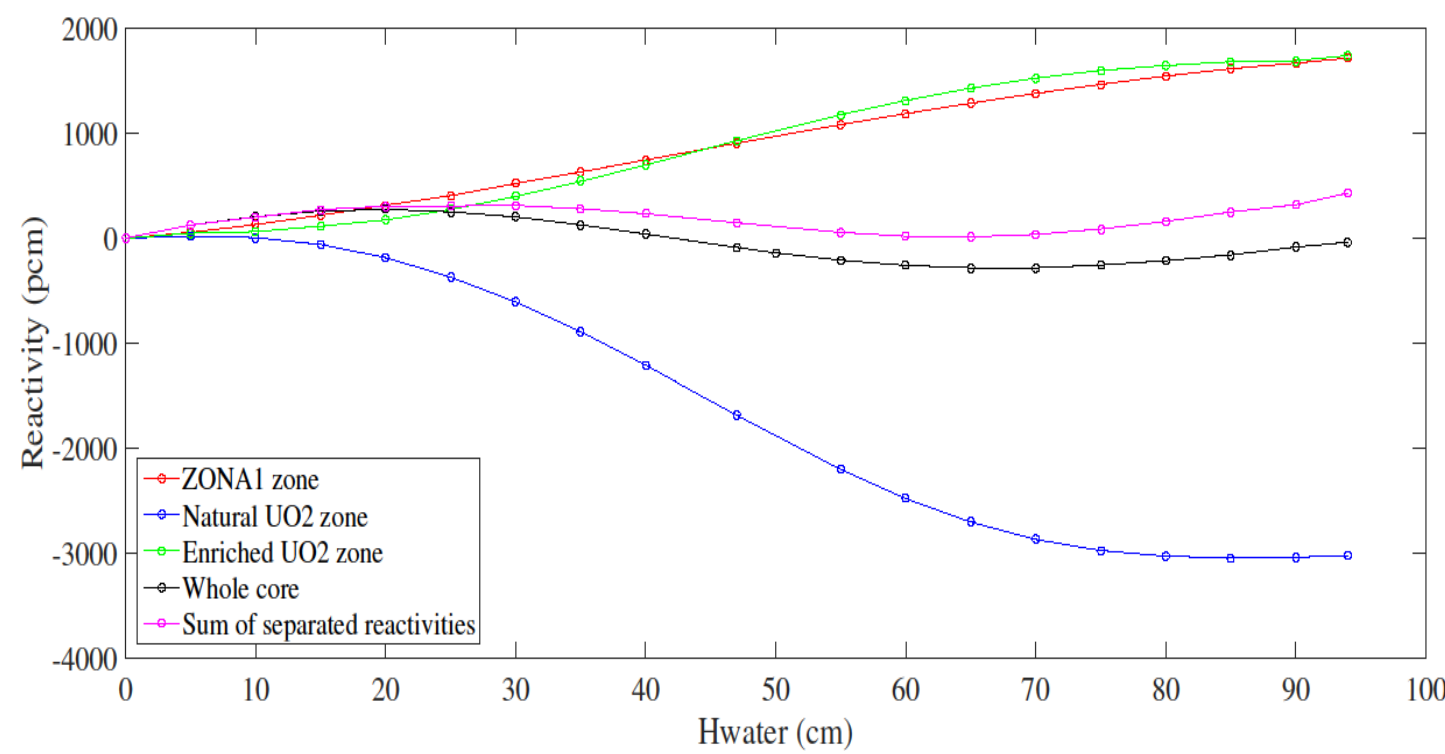

Figure 21: Decomposition of the evolution of reactivity during axial flooding - Optimized configuration with $\mathrm{B}_{4} \mathrm{C}$

Even though the total flooding effect is not rigorously equal to the sum of the individual effects in each zone (because of the spectral modifications between zones), the general behavior is well reproduced. To go forward, sensitivity analyses are performed in order to understand the modifications of the tendency.

As defined in section 4, we compute relative sensibilities of the multiplication factor $k_{\text {eff }}$ to the concentration of various isotopes of interest: ${ }^{1} \mathrm{H},{ }^{235} \mathrm{U} /{ }^{238} \mathrm{U},{ }^{239} \mathrm{Pu} /{ }^{240} \mathrm{Pu} /{ }^{241} \mathrm{Pu},{ }^{10} \mathrm{~B}$ and ${ }^{16} \mathrm{O}$. Those calculations are realized in the optimized coupled core with $\mathrm{B}_{4} \mathrm{C}$ to compare the behaviors in five different water levels in the fast zone: $0,20,45,70$ and $94 \mathrm{~cm}$ (respectively called 1 to 5 below). The results are grouped in the following figures 13 and 14: 


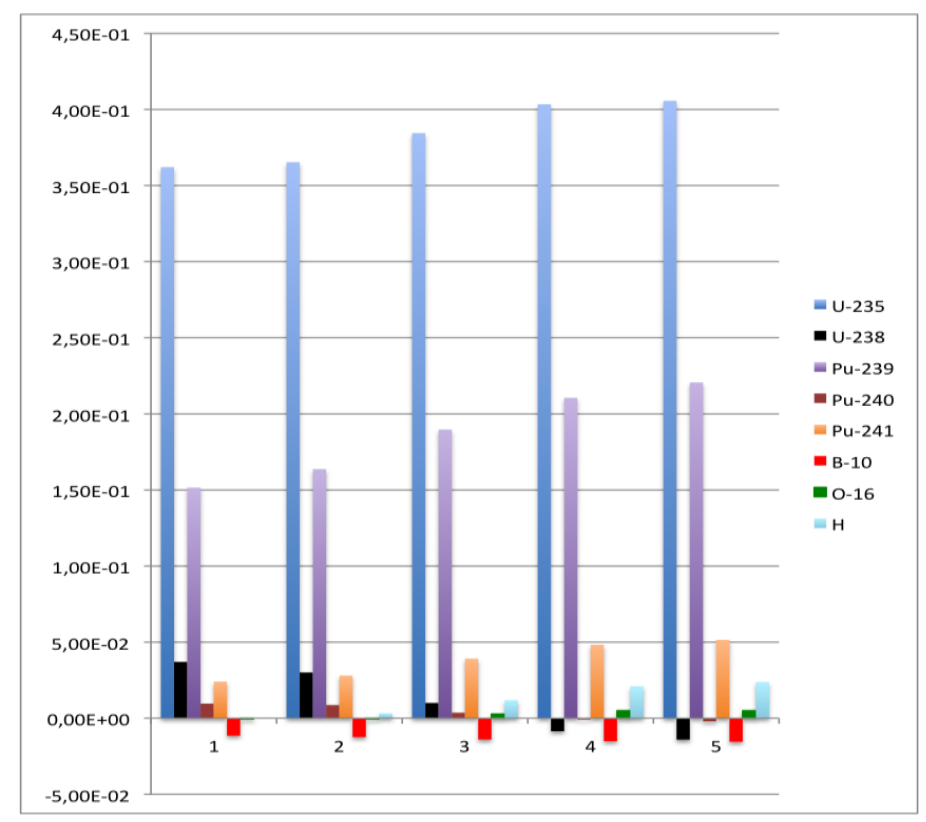

Figure 22: Evolution of sensitivities of $\mathbf{k}_{\text {eff }}$ during axial flooding

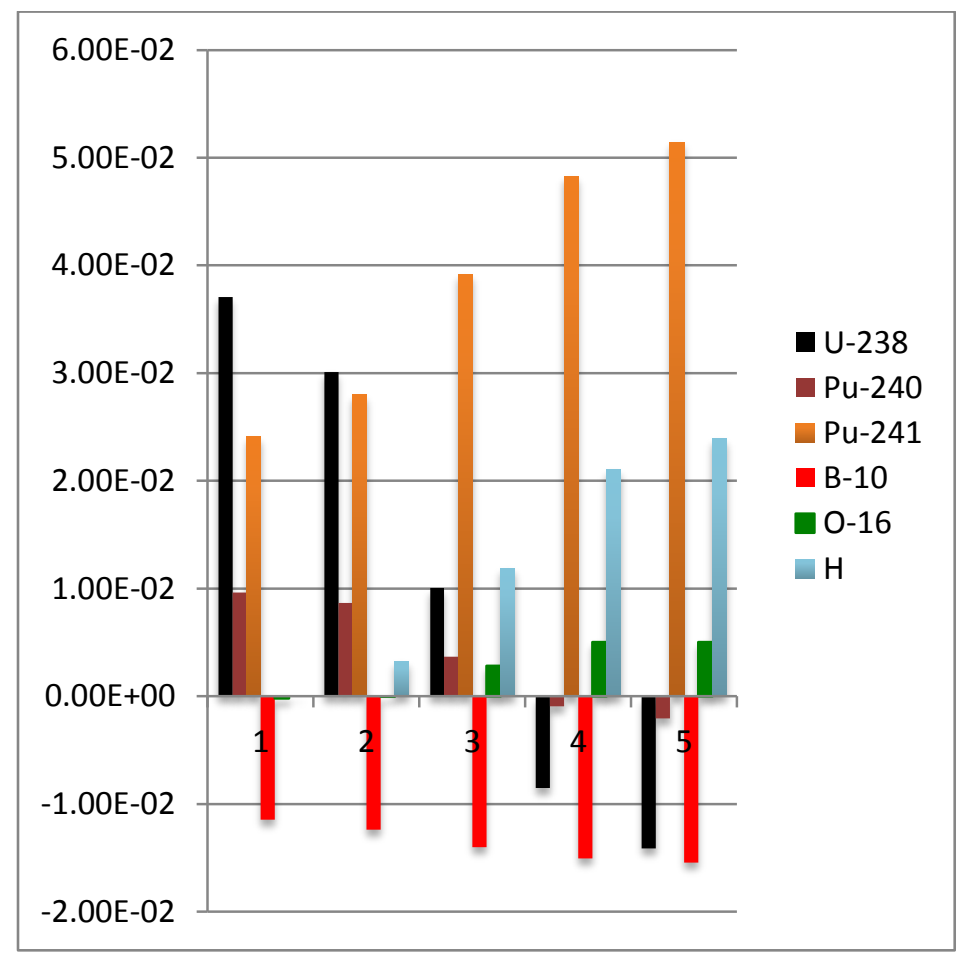

Figure 23 : Evolution of sensitivities of $\mathbf{k}_{\text {eff }}$ during axial flooding (less sensitive isotopes)

Sensitivity coefficients of the $k_{\text {eff }}$ to fissile isotopes $\left({ }^{235} \mathrm{U},{ }^{239} \mathrm{Pu}\right.$ and $\left.{ }^{241} \mathrm{Pu}\right)$ are increasing because of the moderation of the spectrum. This evolution is observed for moderation isotopes $\left({ }^{1} \mathrm{H}\right.$ and $\left.{ }^{16} \mathrm{O}\right)$ as well. As expected, the higher the water level, the stronger is the sensitivity to ${ }^{10} \mathrm{~B}$. But the most interesting case concerns fertile isotopes as ${ }^{238} \mathrm{U}$ and ${ }^{240} \mathrm{Pu}$. As the spectrum is shifted to the epi-thermal energy range, the influence of such isotopes is also shifted, from a positive to a negative contribution to the reactivity. This phenomenon results 
from the competition between the negative capturing component and the threshold positive fission contribution. Then, the modification of the sign of the reactivity observed around $45 \mathrm{~cm}$ water height can be attributed to this changing contribution from a negative to a positive influence. When the water height reaches $70 \mathrm{~cm}$, it starts increasing again due to the thermal shift on the spectrum and its consequences on fissile isotopes.

In a nutshell, more than the value of reactivity obtained, this section demonstrates that the increase of reactivity during a flooding of the fast zone can be contained by an adequate neutronics design. The variation of the reactivity is the consequence of strong opposite effects due to spectrum shifting, especially for threshold cross-sections, and adequate use of thermal absorbers that have a positive impact on the fast flux when the central zone is in air (see sections 3.1 and 3.2).

\section{CONCLUSIONS}

Critical experiments have been widely used to validate calculation tools and also improve the knowledge of nuclear data. Development of experimental programs dedicated to the improvement of nuclear data uncertainties in the fast energy range is necessary within the frame of the development for GEN IV reactors. In this perspective, fast-thermal coupled cores are expected in the future ZEPHYR critical facility to be built in Cadarache by the next decade. By means of several calculations, the physics particularities of fast-thermal coupled cores are investigated, in particular for the spectral adaptation between the fast and the thermal zones. One of the main issue is to ensure that the thermal zone does not degrade fast spectrum characteristics in the oscillation channel, and hence ensure a proper representativeness for reactivity effects. Undemonstrated choices and general deductions can find here a precise and complete justification thanks to Monte-Carlo based validation using TRIPOLI-4® and sensitivity studies. The results presented here demonstrate that:

- A precise design of the adaptation zone in an approximate radius of $35 \mathrm{~cm}$ can produce a fast spectrum as efficient as an entire fast core.

- A thermal low enriched driver zone does not deteriorate the fast central performances.

These two first statements allow a significant reduction of needed fissile materials to perform ZPR experiments representative of fast reactors.

- The practical measurements in fast-thermal optimized coupled cores would bring similar information than the entirely fast cores.

- The optimized configuration presented here has been proved to be stable in terms of neutronics in case of an accidental flooding of the fast zone, which stands for the most severe cause of reactivity injection.

Additional work is ongoing within three main axes. Firstly, it will consist of designing coupled configurations in order to accentuate the epithermal energy range from $10 \mathrm{eV}$ to 10 
$\mathrm{keV}$. Then, a deeper understanding and evaluation of the indirect contributions in sensitivity profiles for small reactivity measurements will be studied taking into account the differences with large reactivity experiments such as rod drops. Finally, it will focus on improving experimental techniques for ZEPHYR and in particular for fast-thermal coupled cores. Beyond measurements of the total variation of reactivity which leads to integral and total cross-sections, experimental techniques such as the simultaneous utilization of both local and global signals would allow a separation of the reactivity effects in their main components. A better experimental characterization of absorption and scattering cross sections could finally be reached.

\section{REFERENCES:}

Archier, P., et al., 2014. COMAC: Nuclear data covariance matrices library for reactor applications. In: Proc. PHYSOR Conference, Kyoto.

Aufiero, M., et al., 2016. Coupled reactors analysis: new needs and advances using MonteCarlo methodology. Ann. Nucl. Energy 98, 218-225.

Avery, R., 1958. Coupled fast-thermal power breeder. Nucl. Sci. Eng. 3, 129-144.

Blaise, P., et al., 2016. The R\&D roadmap for Gen-2,3 \& IV neutronics studies in the future ZEPHYR ZPR in Cadarache. In: Proc. IGORR Conference, Berlin.

Bretscher, M.M., et al., 1970. Low flux measurements of Pu-239 and U-235 capture-tofission ratios in a fast reactor spectrum. Nucl. Sci. Eng. 39, 368-378.

Brun, E., et al., 2015. TRIPOLI-4®, CEA, EDF and AREVA reference Monte Carlo code. Ann. Nucl. Energy 82, 151-160.

Cathalau, S., et al., 2014. More than forty years of neutronics experiments in critical facilities of Cadarache center: from EOLE and MINERVE to the future ZEPHYR reactor. IGORR Conference, Bariloche.

Fahrmann, K., et al., 1981. A fast-thermal coupled system with energy-independent adjoint flux. Kernenergie 24, 431-433.

Foell, W., 1972. Small sample reactivity measurements in nuclear reactors. Am. Nucl. Soc. \& U.S. Atom. Energy Commission.

Gandini, A., 1967. A generalized perturbation method for bilinear functional of the real and the adjoint neutrons fluxes. J. Nucl. Energy 21, 755-765.

Lehmann, E., et al., 1986. The method of energy-independant adjoint flux and its perfection by the SEG-V configuration. Kernenergie 29, 30-33. 
Lehmann, E., et al., 1991. A fast critical reactor assembly with strong energy dependence of adjoint flux. Kernenergie 34, 9-12.

Martin-Deidier, L., 1979. Mesure intégrale de la capture des produits de fission dans les réacteurs à neutrons rapides. $\mathrm{PhD}$ Thesis, Université d'Orsay.

Milosevic, M., et al., 1995. A comparative study of effective delayed neutron fraction. Ann. Nucl. Energy 22 (6), 389-394.

Orlov, V.V., 1980. Problems of fast reactor physics related to breeding. Atomic Energy Review 184, 989-1077.

Palmiotti, G., Salvatores, M., 2011. Impact of Nuclear Data Uncertainties on Innovative Fast Reactors and Required Target Accuracies. J. Nucl. Sci. Technol. 48 (4), 612 - 619.

Pesic, M., 1987. Coupled fast-thermal system at the «RB» Nuclear reactor. Kernenergie, 80,4 .

Pesic, M., 1991. A study on criticality of coupled fast-thermal core HERBE at RB reactor. Ann. Nucl. Energy 18 (7), 413-420.

Rimpault, G., et al., 2002. The ERANOS code and data system for fast reactor neutronic analyses. PHYSOR Conference, Seoul, Korea.

Ros, P., et al., 2016. Fast-thermal coupled cores in ZPR revisited: physical specificities and potentialities for ZEPHYR. PHYSOR Conference, Sun Valley.

Truchet, G., et al., 2014. Continuous-Energy Adjoint Flux and Perturbation Calculation using the Iterated Fission Probability Method in Monte Carlo Code TRIPOLI-4 and Underlying Applications. SNA + MC 2013.

Youinou, G., et al., 2016. Versatile Coupled Thermal-Fast Irradiation Test Reactor. PHYSOR Conference, SunValley. 